\title{
Consumption Taxes and Corporate Tax Planning - Evidence from European Service Firms
}

- This version: 29 October 2018 -

Marcel Olbert

olbert@,uni-mannheim.de

Ann-Catherin Werner

awerner@uni-mannheim.de

University of Mannheim, Business School

\begin{abstract}
:
Consumption taxes are a primary source of tax revenue and, against the common intuition, firms might bear the respective tax burden. However, it is largely unknown how firms respond to consumption taxes. We examine whether service firms in Europe respond to consumption taxes and whether managing sales as the respective tax base is interrelated with subsequent income tax-motivated profit shifting. We exploit corporate affiliate-level panel data and a unique setting in Europe over the period 2007-2015 with 72 staggered and plausibly exogenous consumption and corporate income tax rate changes. We find that firms, on average, exhibit a negative valueadded tax-rate semi-elasticity of reported sales of around 0.5 . Consistent with theory and incentives from the European value-added tax system, the effect is stronger for firms with greater discretion over the jurisdiction of value-added tax liability (firms in the digital service sector) and firms facing greater demand elasticity. We then show that the extent and the channels of profit shifting depend on firms' responsiveness to consumption taxes consistent with managing sales in response to consumption taxes placing a constraint on manipulating transfer prices for intra-group trade. Our study thereby provides novel insights for the design of multidimensional tax systems.
\end{abstract}

Keywords: Consumption Taxes, Tax Planning, Profit Shifting

JEL classification: H22, H24, H25, H32, M48

Acknowledgements: We thank David Agrawal, Jannis Bischof, Don Bruce, Lisa De Simone, Jost H. Heckemeyer, Jing Huang (discussant), Martin Jacob, Ken Klassen, Ilpo Kauppinen (discussant), Rebecca Lester, Katharina Nicolay, Leslie Robinson, Christoph Spengel, Milda Tylaite (discussant), Robert Ullmann (discussant), Johannes Voget, participants at the Accounting Brownbag Seminars at Stanford University and the University of Southern California, at the poster session at the $110^{\text {th }}$ Annual Conference of the NTA, at the ZEW 2018 Public Finance Conference, at the EAA Annual Congress 2018, at the $8^{\text {th }}$ Conference on Current Research in Taxation 2018, at the $4^{\text {th }}$ Berlin-Vallendar Conference on Tax Research, at the 2018 AAA Annual Meeting, and at the $5^{\text {th }}$ Annual MaTax Conference for valuable comments. This research was partly conducted while Marcel Olbert was visiting at Stanford University Graduate School of Business with much appreciated funding by the University of Mannheim Business School and the scholarship granted by the German Academic Exchange Service (DAAD). We are thankful for research travel grants from the Julius-Paul-Stiegler-Gedächtnisstiftung. This paper previously circulated under the title "Corporate Income and Consumption Tax Planning in the Digital Age - Evidence from European Service Firms". 


\section{Introduction}

Consumption taxes are one of the most important tax policy instruments and account for more than 25 percent of the European Union's 2016 EUR 4 trillion tax revenue compared to the less than 10 percent contribution of corporate income taxes. ${ }^{1}$ Profit and consumption taxation can therefore be seen as substitutes for generating tax revenue from the perspective of governments (Dharmapala 2014). Prior research has focused on analyzing the effects of corporate income taxes (CIT) on corporate decisions, but has largely neglected the fact that firms are liable to pay multiple taxes including consumption taxes (Christensen et al. 2001, Keen and Lockwood 2010, Robinson 2012, Scholes et al. 2015, p. 19). ${ }^{2}$ While governments levy consumption taxes with the intent to tax final consumption (by final consumers), firms regularly bear part of the tax burden (Poterba 1996, Fullerton and Metcalf 2002). Against this backdrop, this paper investigates the extent to which firms respond to changes in consumption taxes and whether such behavior explains cross-sectional differences in corporate income tax planning.

Understanding the effects of consumption taxes on firms' decision-making as well as the interplay of consumption and profit taxes is crucial for evaluating tax policy (Robinson and Slemrod 2012, Kopczuk and Slemrod 2006) and for tax management decisions (Scholes and Wolfson 1992). There is an ongoing policy debate on the design of tax systems building on consumption versus income taxation. ${ }^{3}$ Within this context, the historical discourse on the efficiency of company taxation based on profits and capital versus consumption is blooming again. ${ }^{4} \mathrm{~A}$ cash-flow tax in the form of an international corporate consumption tax has been heatedly debated in the United States (U.S.) (Auerbach et al. 2017, Devereux and Vella 2017). ${ }^{5}$ However, a pure consumption tax-based system may not be the perfect solution, as challenges of existing systems demonstrate. The European Commission (2017a, 2018b) attributes an estimated annual loss of EUR 147 billion due to insufficient tax enforcement and collection in combination with firms' incentives and activities to avoid consumption taxes.

\footnotetext{
1 Tax revenue excluding social security contributions, see http://ec.europa.eu/eurostat/statistics-explained/index.php/Tax revenue statistics\#Main tables.

${ }^{2}$ For the remainder of this paper, we use the terms income and direct taxation and consumption and indirect taxation interchangeably. In Europe consumption taxation takes on the form of a value-added tax (VAT).

${ }^{3}$ Especially in the globalized and increasingly digitalized economy, both direct and indirect taxation is a pressing concern of policy makers but empirical evidence on the associated tax challenges is very scarce (European Commission 2014, 2018a; OECD 2015, 2018). Also see Olbert and Spengel (2017) for an overview.

${ }^{4}$ See e.g. Kopczuk and Slemrod (2006); Arnold et al. (2011). Among others, Atkinson and Stiglitz (1976) analyse the merits of indirect vs. direct taxation of individuals and highlight the interdependence of both taxes within a tax system.

${ }^{5}$ Furthermore, there is an ongoing discussion about whether introducing a value-added tax would increase the competitiveness of the U.S. tax system while serving as a stable source of tax revenue (e.g. Graetz 2016).
} 
For businesses in the European Union, consumption taxes exhibit an important cash-outflow given value-added taxes (VAT) are charged on a gross basis (on revenue) at rates of often above 20 percent. In contrast to the simple notion that consumption taxes are borne by the final consumer, economic theory and empirical evidence suggest that the tax burden may partially fall on firms (Fullerton and Metcalf 2002, Poterba 1996, Christensen et al. 2001, Kenkel 2005, Alm et al. 2009, Kosonen 2015). The extent of tax incidence on firms depends on the relative elasticity of supply and demand (Atkinson and Stiglitz 1972, Fullerton and Metcalf 2002). If firms bear part of the tax burden, consumption taxes constitute a cost factor and reduce firms' surplus. Recent evidence supports this view and suggests that VAT and sales tax regimes around the globe have a negative influence on corporate investment (Jacob et al. 2018). This result is attributed to capital demand decreasing in firms' consumption tax burden. We examine this mechanism more directly by focusing on the relationship between VAT and firms' output.

We study the European setting in which multinational enterprises (MNEs) have an incentive to engage in profit shifting, i.e. to report higher (lower) pre-tax profits at the affiliate level in countries with lower (higher) CIT rates. At the same time, firms might strategically report sales in response to consumption taxes (VAT in Europe). Firms' output response to consumption taxes may be driven by two mechanisms: the incidence of VAT falling on firms and decreasing marginal profits or firms exploiting consumption tax planning opportunities to maximize cash flows. We argue that reporting sales in response to consumption taxes may constrain the firm's ability to shift income to optimize income taxes given that sales are one key determinant of pretax income. ${ }^{6}$

We begin our analysis by documenting that firms' output decreases with the VAT rate. We expect and find industry-specific results consistent with the different relevance of VAT for these firms' after-tax cash flows, different proximities to final consumers, and different VAT avoidance opportunities. We subsume this behavior under the notion of corporate consumption tax planning in a wider sense, i.e. either as the result of considering lower marginal profits because of VAT incidence or of strategically reporting sales in low VAT jurisdictions. We further show that firms' consumption tax responsiveness varies with a firm's relative size in the industry, a proxy for its market share that is typically associated with a lower elasticity of demand. We then hypothesize that firms alter their profit shifting behavior depending on their sensitivity to VAT with respect to reported sales. We find that firms' income tax-motivated

\footnotetext{
${ }^{6}$ In the setting of our study, for instance, regulations for both types of taxes overlap such as Articles 72 and 80 of the European VAT directive referring to the arm's length principle for determining tax bases just as the existing international transfer pricing regulation does (Matesanz 2018).
} 
profit shifting activity changes in their propensity towards managing consumption taxes. Consistent with VAT considerations constraining the flexibility to manage pre-tax income, firms' profit shifting behavior via transfer pricing (debt financing) decreases (increases) when they report sales in response to VAT.

The negative relationship between corporate income taxes and multinational enterprises' (MNEs) reported profits is well-documented. ${ }^{7}$ However, there is only limited evidence on why some firms engage in more profit shifting than others (Hanlon and Heitzman 2010). ${ }^{8}$ Further, only a few studies examine whether firms aim to minimize both income and non-income taxes (Robinson 2012) or whether they alter their profit shifting behavior if conflicting incentives between income tax rates and customs duties arise (Swenson 2001, Blouin et al. 2018). Blouin et al. (2018) provide novel evidence that firms face a trade-off between minimizing income taxes and customs duties through transfer pricing. In a similar vein, this paper examines whether there are trade-offs in firms' tax planning behavior with regards to corporate income and consumption taxes. We go beyond existing approaches in the profit shifting literature and integrate consumption taxes in our analysis because they have significant implications for MNEs' taxrelated costs (Christensen et al. 2001, Robinson 2012, Dyreng and Maydew 2018). In addition, practitioners highlight that VAT considerations affect transfer pricing decisions (Ernst \& Young 2013).

We exploit a large panel of affiliate-level financial data from the Amadeus database provided by Bureau van Dijk and empirically investigate how firms react to consumption and corporate income taxes through reporting choices at the affiliate level. Our focus on service providers in the European market offers a unique setting for investigating the effects of direct and indirect taxation on MNEs' tax planning decisions for several reasons. First, economic policy is largely harmonized in the European market. Thus, other policy factors should not confound the analysis. Second, the European market is characterized by open borders in particular with regards to services. As a result, service providers are able to freely locate employees and assets as well as generate cross-border sales within the EU. ${ }^{9}$ Third, consumption taxes play a larger role in the service sector due to proximity to final consumers (Robinson 2012). Forth, there is substantial variation in EU countries' tax policy despite the EU's efforts to ensure a minimum standard of

\footnotetext{
${ }^{7}$ See e.g. Hines and Rice (1994); Huizinga and Laeven (2008); Dharmapala (2014). See Heckemeyer and Overesch (2017) for an overview.

${ }^{8}$ See e.g. Klassen et al. (2014); De Simone (2016); and De Simone et al. (2017).

${ }^{9}$ See e.g. the Digital Single Market initiative, https://ec.europa.eu/commission/priorities/digital-single-market en. The policy objective is to unlock the potential of cross-border electronic trade in terms of a broader range of products and services and lower prices, contributing EUR 415 billion p.a. to Europe's economy.
} 
tax harmonization. In our sample, CIT rates varied from $10 \%$ in Bulgaria to $38.93 \%$ in France in 2015. ${ }^{10}$ VAT rates ranged from $17 \%$ in Luxembourg to $27 \%$ in Hungary. We exploit 40 and 32 plausibly exogenous CIT and VAT rate changes in both directions in the sample period (2007-2015) that provide a favorable setting for identification.

We test the relation of VAT and firms' reported output while controlling for unobserved, time invariant firm characteristics and changes in consumer prices and inflation in order to isolate the response attributable to consumption tax planning from consumer market and macroeconomic effects that might be correlated with tax policy. We find that firms' reported output, measured by sales, exhibits a negative VAT semi-elasticity of 0.5 . This contrasts the traditional view that consumption taxes do not affect corporate decision-making given they are borne by consumers and adds to prior empirical evidence on the tax incidence of consumption taxes.

In cross-sectional tests, we provide evidence consistent with the underlying mechanisms of this behavior and also control for unobserved variation over time at the country-level such as economic conditions and other policy changes. The reaction to VAT due to the tax incidence falling on firms is present for B2C firms, which are always liable to the VAT in their country of incorporation and possibly face more elastic demand due to their proximity to end customers. There is no effect for B2B and intra-group service firms, for which VAT paid is refunded (so-called input VAT) and does not translate into an ultimate financial burden. While VAT is generally due in the country where the consumer is located, which - in theory - provides no incentive to report sales in response to VAT rates, enforcement of this destination rule is considered problematic (OECD 2017a, p. 13). More so, firms offering digital services, such as content streaming and web platforms, are liable for VAT in the country of their incorporation irrespective of the location of the consumer. This differential treatment provides digital service firms with the opportunity to strategically report sales in order to minimize the VAT burden and, thus, obtain a competitive advantage. Consistently, we find the strongest significant association between the VAT rate and reported sales for the subset of digital service affiliates.

Next, we develop and test our hypothesis that focuses on the relationship between a firm's consumption tax responsiveness and its profit shifting behavior. Since taxable corporate profits are defined as the difference between sales and costs of goods sold, manipulating sales as the value-added tax base might constrain the flexibility to react to income tax incentives. Building

\footnotetext{
${ }^{10}$ These rates reflect effective CIT rates without considering special incentives such as the notional interest deduction in Belgium or the 14 IP box regimes in place that substantially lower the effective applicable CIT rate.
} 
on the findings of Blouin et al. (2018), we conjecture that firms' profit shifting behavior depends on the consumption tax sensitivity. We predict that profit shifting behavior is attenuated if firms report sales in response to consumption taxes. We first replicate established profit shifting models (in particular based on Hines and Rice 1994, Huizinga and Laeven $2008^{11}$ ) and document shifting behavior of our sample firms consistent with prior estimates. To examine the relation between consumption tax planning and income tax-motivated profit shifting, we construct a measure of the firm-specific VAT sensitivity with respect to reporting sales and integrate this measure in the analysis of profit shifting. We then extend the baseline model and interact the firm-specific VAT sensitivity with the CIT. Our results indicate that profit shifting behavior is, on average, reduced to an insignificant level if firms' reported sales are negatively associated with VAT rates. We show that only firms that do not report lower sales in response to increasing VAT rates appear to engage in income tax-motivated profit shifting consistent with consumption tax planning placing a constraint on profit shifting opportunities. At the same time, firms facing such constraint appear to more extensively exploit interest expenses as an alternative to transfer pricing as a profit shifting mechanism (Heckemeyer and Overesch 2017).

Our study offers several contributions. First, we study corporate behavior regarding the manipulation of tax bases for different types of taxes, which is highly relevant when deciding on adequate tax policy (Christensen et al. 2001, Keen and Lockwood 2010, Fox et al. 2014). Existing research mostly investigates the effects of direct and indirect taxation on corporate behavior separately. To the best of our knowledge, we are the first to investigate whether and to what extent VAT influences firms' reported output. We identify two mechanisms underlying this behavior. First, firms may bear part of the consumption tax incidence, which causes them to decrease output (Jacob et al. 2018). This behavior is more pronounced for firms facing relatively elastic demand. Second, firms exploit consumption tax planning opportunities. Since we also establish a relationship between this consumption tax channel and corporate income tax planning, we answer the call to comprehensively study the interaction of a tax system's different features and their effect on corporate decision-making (Kopczuk and Slemrod 2006, p. 133134, Robinson and Slemrod 2012, Dyreng and Maydew 2018). In particular, we provide novel evidence on the interplay of profit and consumption taxes.

Second, our study adds to the profit shifting literature. In the vein of Klassen et al. (2014), De Simone (2016) and De Simone et al. (2017), we provide a more nuanced view on profit shifting

\footnotetext{
${ }^{11}$ We use the CIT rate at face value in contrast to the tax incentive variable put forward by Huizinga and Leaven (2008) since we do not include non-service affiliates of the MNE groups in our sample and we investigate the VAT-motivated sales reporting behavior separately.
} 
incentives. ${ }^{12}$ We add to the recent findings of Blouin et al. (2018) and show that firms consider both income and consumption taxes in their tax planning strategies and that there is a trade-off with respect to minimizing the respective tax burdens. Overall, our results indicate that firms' responsiveness to consumption taxes might explain why some firms appear not to engage in income-tax motivated profit shifting (Hanlon and Heitzman 2010, Dharmapala 2014).

Finally, we provide insights with direct policy implications. We deliver evidence that digital service firms make use of the resulting competitive advantages, potentially adding to the European Commission's estimated annual loss in VAT of EUR 147 billion. We note that digitalization is not necessarily associated with more aggressive profit shifting behavior but might be of greater relevance for minimizing consumption taxes and thereby inform the debate on whether aggressive tax planning is exacerbated in the digital economy (OECD 2015). Overall, the insights on service firms' output decreasing in VAT are important for at least two reasons. First, our results suggest that both consumption taxes and income taxes affect corporate reporting behavior and decision-making. Second, our results suggest that consumption-oriented systems are not the solution to all problems attributed to tax planning behavior under profit taxation since indirect tax evasion exists and can be associated with distortions in production decisions (Virmani 1989).

The remainder of the paper is organized as follows. In section two, we elaborate on the institutional background and derive our hypotheses for taxing sales and profits of service providers in Europe. Further, we motivate our study on the effects of consumption taxes and revisit prior literature on tax-motivated profit shifting. In section three, we describe our research design and the data. In section four, we present the results of our empirical tests. Section five concludes.

\section{Institutional Background, Related Literature and Hypotheses}

\subsection{Value-added Taxation of Service Providers in Europe}

For a vast number of countries, indirect (including value-added) taxes are the most relevant type of tax and the key instrument of raising tax revenue. ${ }^{13}$ Value-added taxation in the EU is largely harmonized across the member states. Legislation on EU level defines the place of supply of goods and services (i.e. where the tax has to be remitted) and other features of the system, such as the debtor of the tax and the mechanism of remittance. Member states, however, are

\footnotetext{
${ }^{12}$ Dharmapala (2014) also documents that the heterogeneity across previous studies has not been studied closely yet.

${ }^{13}$ E.g. in the European Union VAT makes up for EUR 1,044 billion compared to taxes on income of corporations of EUR 391 billion for the year 2016 (Eurostat 2018a). The U.S. collect less in sales taxes and more in CIT (about 60\%) (Engelen 2017).
} 
free to choose the applicable VAT rate with a minimum threshold of 15 percent. As of 2015, VAT rates in the EU varied considerably between 17 and 27 percent. VAT is due on every sale of a company. The seller has to remit the tax independently of the nature of the transaction and the legal form of the buyer such that value-added taxes are collected on every stage of the value chain. In the case of business-to-business (B2B) transactions, the buyer as a business itself is granted a credit to subtract the tax from future tax remittances (input tax credit). In the case of business-to-consumer (B2C) transactions, the VAT becomes final at the stage of the consumer who is supposed to bear the ultimate burden of this type of consumption tax. ${ }^{14}$ Figure 1 illustrates the VAT collection and remittance process.

The place of supply of services determines the tax liability and, thus, which country's VAT is applied to the sale. As a general rule in the EU VAT system, the place of supply follows the destination principle. ${ }^{15}$ The place of supply is in the country where the final consumer is located (destination principle) and enforcement is comparable to sales taxes in a U.S. cross-state context (Fox et al. 2014). Consequently, exports are zero-rated and imports are taxed at the importing country's rate. Many B2C services, however, are taxed where the supplier is established (origin principle). ${ }^{16}$ Since firms offering B2C services of digital nature, i.e. services delivered electronically or online, had a competitive advantage by reporting remote sales in low VAT jurisdictions or avoiding the tax, the destination principle was introduced for this subgroup of services in $2015 .^{17}$

These varying place of supply rules result in different tax consequences for the respective service companies. Enforcement of the destination rule is considered problematic for the collection

\footnotetext{
${ }^{14}$ In contrast, under the U.S. sales tax system only B2C transactions trigger a seller's tax liability if the seller has a nexus in the consumer's location. Sales to businesses as well as exports are directly exempt while imports are taxed at retail. Sales taxes are levied at state level on intrastate retail transactions with rules varying across states and states are unable to tax inter-state commerce. Regarding purchases made outside but used within a state, the customer needs to declare and remit use tax. However, compliance with the use tax is said to be very low. Since sellers only need to collect sales tax if they have a physical presence (nexus) in that state, this regulation ultimately results in an exemption of B2C remote sales (McLure (2002), p. 137; Bal (2015), p. 246). The mechanism of collection and remittance presents the main difference between the EU VAT and US sales tax system (Slemrod 2008; Pomeranz 2015).

${ }^{15}$ Different place of supply rules apply depending on what type of goods or services are sold to what kind of customer.

${ }^{16}$ For B2B services, the place of supply used to follow the origin principle until 2009, (Article 44 of Directive 2008/8/EC, introduced on 1 January 2010). The destination principle also applies to B2C services such as advertising services, services of consultants and lawyers, financial services, telecommunications services, broadcasting services and electronically supplied services provided to customers established in a non-EU country (Article 56 of Directive 2006/112/EC, now Article 59 of Directive 2008/8/EC). For the full list of exceptions, see Articles 46-50 and 53-57 of Directive 2006/112/EC.

${ }^{17}$ Article 58 of Directive 2008/8/EC of 12 February 2008 amending Directive 2006/112/EC. Digital services provided by service providers established in a third country (non-EU) to private consumers have been taxed according to the destination principle since 2003 (Article 57 of Directive 2006/112/EC, now Article 58 of Directive 2008/8/EC).
} 
of VAT on both digital B2C services and B2B supplies. ${ }^{18}$ We use the resulting consumption tax planning opportunities to validate our main findings in cross-sectional tests. For instance, there is anecdotal evidence that especially multinational digital service providers report sales primarily in their European subsidiaries in low VAT rate countries in order to sell their services in the European market at more competitive prices. ${ }^{19}$

Recent proposals on EU level aim to improve the enforcement mechanism for B2B supplies of goods ${ }^{20}$ and a recent VAT package should implement provisions such that platforms are liable to collect and pay VAT on $\mathrm{B} 2 \mathrm{C}$ imports. ${ }^{21}$ Examining the functioning of existing rules is therefore of utmost importance in order to evaluate the potential efficiency of new regulations.

\subsection{Effects of Consumption Taxes on Corporate Decisions}

Consumption taxes can affect firms' output and their profitability in two ways. First, consumption taxes may be partially borne by firms. Consumption taxes drive a wedge between the price consumers pay and the price producers receive and the incidence of consumption taxes depends on the relative elasticity of supply and demand (Fullerton and Metcalf 2002). A full passthrough of the consumption tax burden to the final consumer occurs when demand is fully inelastic. In contrast, if consumers are perfectly elastic ${ }^{22}$, the firm bears the full burden of the tax and its net of tax output will be lower than in a world without consumption taxes (Fullerton and Metcalf 2002, Alm et al. 2009). Several empirical studies focus on specific product markets and show that firms partially bear the consumption tax burden which is attributed to consumers' price elasticities not being fully inelastic or supply not being fully elastic (Poterba 1996, Besley and Rosen 1999, Kenkel 2005). ${ }^{23}$

If a firm bears part of the tax burden, the VAT constitutes a cost to the business. ${ }^{24}$ The consequence is a lower surplus for firms to the extent of the unshifted tax burden and the incentive to avoid consumption taxes (Christensen et al. 2001, Fox et al. 2014). When firms expect a lower return, output should be negatively associated with consumption taxes also in a purely domestic setting. In an international setting, MNEs might report lower output in affiliates facing

\footnotetext{
${ }^{18}$ OECD (2017a), p. 13; Hellerstein (2016); Lamensch (2016); Agrawal and Fox (2017).

${ }^{19} \mathrm{Scott}(2015)$.

${ }^{20}$ European Commission (2017c); see van de Leur (2017) for some comments.

${ }^{21}$ Lamensch (2018).

${ }^{22}$ Studies on consumers' purchasing behavior document that consumers are sensitive to consumption taxation (Goolsbee 2000; Einav et al. 2014; Ellison and Ellison 2009; Scanlan 2007; Anderson et al. 2010; and Baugh et al. 2014).

${ }^{23}$ Also see Harding et al. (2012); Kosonen (2015); and Yilmazkuday (2017).

${ }^{24}$ In a discussion of new proposals for cross-border B2B VAT rules, van de Leur (2017) points out that a comprehensive application of the destination principle possibly results in cash-flow disadvantages, thereby influencing profit margins of businesses operating across borders.
} 
higher VAT rates given the return in these countries is lower since net prices must be adjusted downwards if the consumption tax burden is not fully shifted to consumers (Jacob et al. 2018).

The impact of a firm's VAT incidence is illustrated through the example in Figure 2. Assuming that company B is located in a country with a VAT rate of initially $20 \%$ and the rate now increases to $30 \%$, the company can increase the price proportional to the VAT increase such that the gross price is 260 (net price 200 plus 60 VAT) if the consumers are fully inelastic. In this case, the consumer bears the full burden of the VAT increase and company B's net of VATprofit is $100(=260-60-130+30)$. If, however, the consumer demand is perfectly elastic, company $\mathrm{B}$ is not able to increase the price after the VAT increase and will still only be able to charge a gross price of 240 which includes VAT of $55.38(=(240 / 1.3) * 30 \%)$. B then realizes a net profit of only $84.62(=240-55.38-130+30)$. As a result, company B expects lower profits after the VAT increase and might adjust output accordingly.

The second channel is firms manipulating output in order to avoid consumption taxes in a crossborder context, where tax planning incentives arise from cross-border differences in VAT rates. In principle, sales reported in financial statements are assumed to be relatively non-manipulable since the location of (final) consumers is fixed (Dyreng and Markle 2016). Given an MNE has an affiliate in a specific market country, sales should thus be reported in the same country where the consumers are located. However, from a legal and financial reporting perspective, an MNE has the possibility to report cross-border service sales in any affiliate located in a different country than the consumer's location if the respective affiliate becomes the contracting partner of the consumer in the course of the service transaction. There is no incentive to manipulate the location of reported sales at the affiliate level from a consumption tax perspective if the destination principle is consistently enforced (i.e. VAT would be remitted where the final consumer is located). However, collecting consumption taxes is particularly challenging when firms use internet technologies to generate sales (Agrawal and Fox 2017, Agrawal 2017) and some firms offer services that do (or did) not fall under the destination principle such as B2C digital services.

Given an MNE delivers services that are taxed in the country where the service providing affiliate is incorporated (such as providing digital content), the consumption tax planning strategy would be to report revenue from cross-border digital service sales in countries with low VAT rates independently of where services are provided. Amazon used to channel the majority of its internet transactions through its European sales branch Amazon EU SARL, incorporated in Luxembourg providing VAT rates of $3 \%$ on electronic books and $15 \%$ on other services, thus 
providing anecdotal evidence for consumption tax planning. ${ }^{25}$ The literature further suggests that U.S. electronic retailers (e-tailers), in contrast to brick-and-mortar businesses, avoid a taxable nexus when consumption taxes rise (Bruce et al. 2015) and therefore generate financial benefits (Hoopes et al. 2016).

The evidence on the incidence of consumption taxes partially falling on firms and the tax planning incentives arising in the European VAT setting leads to our first hypothesis.

\section{H1: The reporting of sales by MNEs' affiliates in the service sector is negatively associated} with the value-added tax rate in the respective jurisdiction.

\subsection{Tax-motivated Income Shifting}

International taxation of corporate profits follows the separate entity principle, i.e. taxable profits of an MNE's affiliate in a given country depend on transfer prices for intercompany transactions, which must conform to the arm's length principle (Keuschnigg and Devereux 2013, OECD 2017b). Since income tax rates differ widely across countries, MNEs have an incentive to employ transfer pricing strategies within the range of the arm's length principle such that pre-tax profits of an MNE's group of affiliates are primarily reported in low tax countries.

In a meta-analysis of prior empirical studies, Heckemeyer and Overesch (2017) calculate a semi-elasticity of profits with regard to corporate income taxes of 0.8 as a consensus measure and conclude that transfer pricing and licensing are much more relevant channels of profit shifting than intracompany debt financing. Some recent studies explicitly examine different incentives for profit shifting behavior across firms. De Simone (2016) finds that the adoption of IFRS is associated with stronger tax-motivated profit shifting which is explained by the fact that a wider set of benchmarks to defend transfer prices is available. De Simone et al. (2017) focus specifically on loss making affiliates and provide evidence that there is a shift-to-loss effect. Preliminary results by Chen et al. (2017) suggest that profit shifting out of high-tax countries decreases after the introduction of reduced income tax rates on income related to intellectual property (innovation boxes).

Apart from these studies, there is little evidence on cross-sectional differences in profit shifting behavior such as industry-specific opportunities or constraints. ${ }^{26}$ Limited evidence supports the

\footnotetext{
25 The Court of Justice of the EU repealed the excessively low rate in March 2015 forcing an increase in Luxembourg's VAT rate on all revenue from digital services to $15 \%$. See the exemplary media coverage of Amazon and its sale of ebooks through Luxembourg (The Guardian (online) 24 October 2012, and The Guardian (online) 23 May 2015).

${ }^{26}$ Typically, empirical studies apply industry-fixed effects in order to control for unobservable features that may drive the results. But none of the studies reviewed investigates industry-specific shifting behaviour.
} 
OECD's claim that intangible assets facilitate more aggressive profit shifting (Grubert 2003, Beer and Loeprick 2015). Klassen et al. (2014) are the first to provide evidence that firms in the digital economy might engage more actively in corporate income tax planning. They develop a model of electronic commerce reducing the cost of profit shifting and empirically snow that U.S.-based multinational manufacturing firms with a high share of sales generated electronically (i.e. high e-commerce intensity) report significantly lower cash effective tax rates at the consolidated parent level.

Inferring from the extant literature on income tax-motivated profit shifting that documents a negative association of MNEs' reported profits and corporate income taxes, we conjecture that MNEs active in the service industry are also sensitive to corporate income tax rates (Hebous and Johannesen 2016). Given the fact that prices at arm's length are often difficult to observe for services and intangible assets (OECD 2017b, De Simone et al. 2017), we expect that service suppliers have a leeway to shift profits across locations and expect to confirm results of prior empirical investigations (see Heckemeyer and Overesch 2017).

Our study aims to identify whether income tax-motivated profit shifting depends on MNEs' response to consumption taxes. The extent to which firms are sensitive to consumption taxes (VAT) with respect to reporting output (sales) should affect profit shifting behavior due to the fact that sales are a main determinant of reported pre-tax profits (precursor in the income statement). Research on tax planning behavior of firms facing opportunities to optimize both types of the firm's ultimate tax burden is scarce. Swenson (2001) is the first to document that firms show a strong objective to reduce non-income taxes, which in turn alters their transfer pricing strategies used to minimize direct taxes. Robinson (2012) examines non-income taxes (including consumption taxes), their determinants and the relation to income tax planning and tax compliance. She conjectures that firms who engage in income tax avoidance may also try to avoid non-income taxes and empirically finds a positive association of income tax planning activities and non-income taxes paid. In a recent study, Blouin et al. (2018) investigate U.S. MNEs' cross-border transfer pricing strategies and consider that transfer prices do not only determine corporate income tax bases but also form the tax base for import duties. For instance, optimizing the MNE group's CIT liability would require charging a high transfer price from the U.S. to the importing country but at the same time, this strategy might be adverse if the importing country charges high import duties. ${ }^{27}$ This finding is consistent with a substantial

\footnotetext{
${ }^{27}$ Blouin et al. (2018) analyze the association of reported pre-tax profits of foreign affiliates with profit tax incentives measured as the tax rate differential in the presence of conflicting incentives from custom duties and find that profit shifting is attenuated when custom duties and income taxes cannot be jointly minimized, i.e. the higher the
} 
fraction of firms (21 percent) surveyed by EY indicating to take custom issues fully into account in their transfer pricing strategy. Even more firms (27 percent) state that VAT considerations affect their transfer pricing decisions (Ernst \& Young 2013).

Similar to Blouin et al. (2018), we argue that income tax-motivated profit shifting is weaker when firms integrate the incentive to minimize another type of tax. The intuition is that an MNE's affiliate might have reported sales in order to manage VAT (active tax avoidance in the international setting) or in response to an increased tax burden as a major tax planning objective (tax incidence). The level of sales as a major driver of pre-tax profits is thus determined under consumption tax considerations and might not be optimal from a transfer pricing perspective. As a result, the opportunities to shift profits out of high CIT rate or into low CIT rate countries are constrained. Profit shifting becomes more costly under consumption tax planning since all remaining profit shifting activity rests on the cost side of internal trade. We therefore hypothesize the following.

H2: The negative association between reported pre-tax profits and income tax rates is attenuated for firms with a higher consumption tax rate sensitivity w.r.t. reporting sales.

\section{Research Design and Data}

\subsection{Sales Reporting and Consumption Taxes}

We begin our empirical investigation with affiliates' sales reporting behavior in response to VAT. We draw on the industrial economics literature, which examines the input productivity of labor and capital assets with respect to firm value added (sales). The function relates output (measured by sales) to input in the form of labor, capital assets and country-specific economic conditions (GDP, indexed consumer price level, and inflation rate) in the form of a transformed Cobb-Douglas production function. In the vein of Brynjolffson and Hitt (2003), who add computer capital stock as an input variable next to ordinary capital stock and labor, ${ }^{28}$ we augment this empirical specification by including VAT as a potential explanatory variable of sales.

$$
\begin{aligned}
& \text { (1) } \text { LogSalesit }= \\
& \alpha_{0}+\alpha_{1} \text { VAT }_{i t}+\alpha_{2} \text { CIT }_{i t}+\alpha_{3} \text { Multi }_{i} * V A T_{i t}+\alpha_{4} \text { Multi }_{i} * \text { CIT }_{i t}+\alpha_{5} \text { Ttc }_{-} C_{i t} \\
& +\alpha_{6} \text { LogPexp }_{i t}+\alpha_{7} \text { LogAssetsit }_{i t}+\alpha_{8} \text { LogGDP }_{i t}+\alpha_{9} \text { LogConsPrice }_{i t}+\alpha_{10} \text { Inflation }_{i t}+F E+\varepsilon
\end{aligned}
$$

after-tax duty burden (the income tax differential) relative to the income tax differential (the after-tax duty burden), the more (less) stringent the conflict of incentives.

${ }^{28}$ See Cardona et al. (2013) for an overview. They document that studies on (factor) productivity at the firm-level apply similar specifications with sales/revenues as the dependent variable. 
We employ firm fixed effects to account for unobserved firm-specific characteristics that are constant over time such as firm-specific productivity attributes, the consumer price elasticity a firm faces, or its propensity towards tax planning. This fixed effects strategy leads to an identification of firms' response to consumption taxes through tax rate changes over time. We further use year fixed effects to control for time trends causing differences in the level of reported sales. We also include the CIT rate to control for any income tax-motivated sales reporting behavior. We cluster standard errors at the affiliate-level. Our main coefficient of interest in equation (1) is $\alpha_{1}$, which accounts for the response of firm output to the value-added tax rate. We expect a negative sign of the coefficient since we conjecture that firm output negatively reacts to VAT rate increases. To account for cross-sectional differences in behavior, we include interaction terms of the cross-sectional indicator variable and tax rates. In our first set of tests, we specifically test for a differential behavior of foreign-owned firms, denoted by Multi.

The identifying assumption is that a change in the level of an affiliate's reported sales is caused by the VAT rate change in a given country and not by other confounding factors that might be associated with this change in tax policy. A primary concern could be that the conjectured negative association is driven by unobserved variation in economic conditions that are likely to affect tax policy rendering the variation in VAT rates endogenous. To mitigate this concern, we exploit 32 changes in VAT rates in opposite directions, at different points in time, and across different countries. This setting of staggered tax policy changes provides for treated and untreated countries throughout the sample period. Since we focus on affiliates in the European Union only, we are confident to observe changes in reported sales caused by VAT rate changes since the group of untreated affiliates in countries without tax rate changes serve as counterfactuals facing similar economic conditions since we control for a country's GDP (see e.g. Heider and Ljungqvist 2015). Since responses in reported sales (output) to VAT rate changes might be driven by altering consumer demand after VAT rate changes, we include indexed consumer price levels ${ }^{29}$ to mitigate the concern of omitted variable bias and to disentangle the changes in reported sales attributable to firms' response to VAT from consumer market effects. Another concern would be that an MNE's affiliate location choice is endogenous (i.e. affected by tax factors) leading to a sample selection bias. We assume a firm's group structure and affiliate locations to be fixed in our setting in which tax changes are exploited via managing tax bases

\footnotetext{
${ }^{29}$ Price level indices are based on price level differences across countries (drawing on purchasing power parities) and express the price level of consumer goods and services in a given country relative to the average of EU28 countries. We use the sector specific price level indices for "total services" provided by Eurostat (2018b).
} 
since firm-group boundaries change slowly and can be considered exogenous in the short term (Khanna and Yafeh 2005).

To further corroborate any effect of consumption taxes on firms' output, we employ a more stringent model in subsequent analyses including country-year fixed effects. This strategy accounts for any time-varying shocks that might be heterogeneous across countries and affect tax policy and firm output simultaneously. Since VAT changes are absorbed by this type of fixed effects, we cannot identify a baseline effect of VAT on sales. Instead, we interact the VAT rate with the cross-sectional indicators to validate our baseline result. Any significant difference should be the result of cross-sectional differences in VAT incidence or tax planning behavior.

\subsection{Profit Shifting in the Presence of Consumption Taxes}

To test our second hypothesis, we empirically analyze whether firms integrate both types of taxes in their decision-making about tax planning and whether income tax avoidance via profit shifting is affected by a firm's sensitivity to VAT with respect to reporting sales. We address this question by first analyzing a firm's sales reporting behavior, which ultimately affects the level of pre-tax profits to be reported from a financial accounting perspective.

We construct a VAT sensitivity measure that captures the firm-specific association between VAT and reported sales. We derive this measure by running a regression based on equation (1) (excluding interaction terms) with VAT interacted with the firm-level fixed effects vector. ${ }^{30}$ The firm-specific VAT sensitivity is then the point estimate for a firm's fixed effect interacted with VAT. The result is multiplied by -1 and labelled $\triangle V A T$. A positive value for $\triangle V A T$ thus indicates a negative relationship between VAT rates and firms' reported sales. This measure operationalizes our notion of a firm-level consumption tax sensitivity. We augment established profit shifting models in the tax and accounting literature ${ }^{31}$ by including the firm-specific VAT sensitivity as an explanatory variable and interact it with the CIT rate. In particular, we adapt the model developed by Hines and Rice (1994) $)^{32}$ to estimate the effect of the CIT rate on affiliates' reported profits. Our specification follows the typical design using year and firm fixed effects.

\footnotetext{
${ }^{30}$ This fixed effects regression including interaction is implemented in Stata using the high dimensional fixed effects regression estimator by Correia (2016).

${ }^{31}$ Numerous studies on tax-motivated income shifting build on the research design developed by Grubert and Mutti (1993) and Hines and Rice (1994) (extended by Huizinga and Laeven (2008)). Recent studies on the effect of income taxes on firms' profit reporting also include Klassen and Laplante (2012); Dharmapala and Riedel (2013); Dyreng and Markle (2016); and Dowd et al. (2017).

32 Similar empirical specifications providing evidence consistent with income tax-motivated profit shifting are also used by De Simone (2016) and Blouin et al. (2018). Since the sample in this paper only includes MNE affiliates
} 
(2) LogEbitit $_{\text {- }}$

$\beta_{0}+\beta_{1} C_{T} T_{i t}+\beta_{2} V A T_{i t}+\beta_{3} \Delta V A T_{i}+\beta_{4} \Delta V A T_{i}{ }^{*} C I T_{i t}+\beta_{5} \Delta V A T_{i}{ }^{*} V A T_{i t}$

$+\beta_{6} \operatorname{LogPexp}_{i t}+\beta_{7}$ LogAssetsit $+\beta_{8} \log G D P_{i t}+F E+\varepsilon$

We employ firm fixed effects to control for unobserved variation on the affiliate-level that might influence tax responses and financial reporting choices. ${ }^{33}$ We further include year fixed effects to control for unobserved variation over time that affects all affiliates in the sample equally. Our coefficient of interest in equation (2) is $\beta_{4}$, which accounts for the differential effect of CIT on LogEBIT depending on the level of the firm-specific VAT sensitivity with regards to sales reporting. We expect a positive sign of the estimate since we conjecture that profit shifting behavior is attenuated when firms are sensitive to VAT when reporting sales $\left(\beta_{4}>0\right)$.

\subsection{Sample Selection and Variable Definitions}

We use financial information on the affiliate-level of MNEs over the period 2007 to 2015 from the Amadeus database provided by Bureau van Dijk to empirically test our hypotheses. ${ }^{34}$ The database provides unconsolidated financial statement and ownership information for independent and affiliated European firms as well as a detailed industry classification (4-digit NACE Codes).

Our sample consists of active subsidiaries, i.e. affiliates of a group of companies, in the service industry. We categorize service affiliates according to the respective NACE Rev. 2 codes. ${ }^{35} \mathrm{We}$ download financial information from Amadeus for affiliates in the service sector with unconsolidated financial accounts, ultimately owned by a global parent, and with information on reported sales and total assets in at least one of the years from 2013 to 2016 . We further limit the sample to firms with available information on sales and personnel expenses or the number of employees for the year 2015. To cover only firms with at least some tax planning opportunities we drop observations with less than 500,000 Euro in sales and at least 10,000 Euro in total assets and personnel expense. We further drop observations for which total shareholder funds

in the service sector, we use the CIT rate at face value that might drive firms' reporting behavior instead of the tax incentive variable put forward by Huizinga and Leaven (2008).

33 Our preferred specification deviates from other traditional models such as the one of De Simone (2016) and Blouin et al. (2018) in that we replace industry by firm fixed effects to ensure profit shifting responses to CIT changes are not driven by any omitted, time-invariant firm characteristics that are not absorbed by industry-specific factors.

${ }^{34}$ Coverage for 2016 is low due to the time lag of including available financial data in the Amadeus database.

${ }^{35}$ We include firms operating in the services industry with their main activities in one of the following classifications based on NACE Rev. 2 codes: 454, 461, 479, 49, 50, 51, 52, 53, 58, 59, 60, 61, 62, 63, 69, 70, 71, 73, 74, 77, $78,79,80,81,82,8559,90,91,92,93,95,96$. For a detailed description of industry segments, see European Communities (2008). This also means we require an industry classification (NACE) code available in the data. 
are negative in all years (this eliminates especially small firms), which have a missing or above 1 leverage ratio (insolvent firms), with EBIT over sales margins of greater 1 or smaller -1, and which have an effective tax rate of greater than 100 percent or smaller than -100 percent (implausible observations). Since we complement our tests of consumption taxes on firm output with an analysis on the MNE-group level, the regressions are based on affiliates which we can link to an MNE-group based on its global ultimate owner (GUO). Further limiting the sample to affiliates in EU member states and with positive values for EBIT yields 316,900 affiliateyear observations (Table 1). These cover 78,954 unique affiliates with 63,958 global ultimate owners.

All variables are defined in Table 2. We analyze reported sales, measured as the natural logarithm of sales, LogSales, and reported pre-tax profits by earnings before interest and taxes (EBIT, pre-tax income), measured as the natural logarithm of EBIT, LogEbit, on the affiliatelevel. Our tax measures as the variables of interest are the country-year value-added tax rate, $V A T$, and the country-year corporate income tax rate, CIT. The other independent variables reflect firm and country characteristics. Our proxy for labor is personnel expenditure, LogPexp. To proxy for capital we use total assets, LogAssets. We measure the gross domestic product (GDP) as the natural logarithm of GDP per capita in current prices, $\log G D P$, provided by the Worldbank. LogConsPrice refers to the natural logarithm of comparative (indexed) consumer price levels (for the total service sector) and Inflation refers to the country-specific rate of inflation in Europe, both available from Eurostat. Since compliance is considered a major burden with respect to remitting consumption taxes (Bal 2017, European Commission 2016), we also include a proxy for the compliance cost, measured as the time to comply in hours per year, Ttc_ct, provided by the Worldbank and PwC.

[Insert Table 1 about here]

[Insert Table 2 about here]

4. Empirical Results

\subsection{Descriptive Statistics}

Table 3 reports summary statistics of the regression analyses. Our sample of 316,900 affiliateyear observations has average sales of $€ 20.92$ million and EBIT of $€ 1.85$ million over the period 2007-2015. The sample firms report average personnel expenditures of $€ 4.36$ million and total assets of $€ 28.99$ million. In Table 4, we provide a correlation matrix that includes most of our variables. The correlation between $V A T$ and Sales is negative (-0.031), suggesting that VAT is negatively associated with output and thus providing some preliminary support of 
our first hypothesis. The correlation between CIT and Ebit is negative (-0.008), indicating firms report lower pre-tax profits in countries with higher corporate income tax rates.

[Insert Table 3 about here]

[Insert Table 4 about here]

The average CIT rate amounts to $31.01 \%$ and the average VAT rate across country-years is 20.60\%. Table 13 in the Online Appendix shows the CIT and VAT rate changes in percentage points over the period 2007 to 2015 for our 24 sample countries. In total, we observe 72 staggered tax rate changes providing a favorable setting for identification. Panel A of Table 13 documents 4 decreases and 28 increases of the VAT rate. Panel B of Table 13 documents 32 decreases and 8 increases of the CIT rate. Changes in the VAT and CIT rate occur in different years, in different countries and in opposite directions. Hence, the tax rate changes are staggered in time across countries.

We are confident to capture the majority of service providers generating sales to external parties in Europe when comparing the total sales of affiliates classified as offering information and communications services (NACE 58-63) in our sample to the consolidated statistics for this segment provided by Eurostat. ${ }^{36}$ Table 14 in the Online Appendix shows that our dataset captures a larger amount of sales than the consolidated statistics of Eurostat that, for instance, has no information on services sales in Ireland. We thus believe our sample to be representative for the European service sector. Yet, the larger amount of aggregated sales in the sample might also be driven by us capturing intracompany sales, i.e. sales from services offered to other firms of the same multinational group.

\subsection{Sales Reporting and Consumption Taxes}

\section{Baseline Results}

Table 5 reports the results of estimating service affiliates' sales reporting response to VAT rate changes (equation (1)). All specifications in Table 5 include firm and year fixed effects. Column (1) in Table 5 first reports results of estimating a standard production function. Intuitively, the coefficients on LogPexp, LogAssets and LogGDP are all positive and significant. The negative and significant coefficient on $\log C$ ons Price suggests that reported sales decrease in consumer price levels (elasticity of around 0.22 ) hinting at a somewhat elastic consumer demand, i.e. higher consumer prices translate into lower output (firms' sales) if they face non-zero demand

\footnotetext{
${ }^{36}$ Available at http://ec.europa.eu/eurostat/statistics-explained/index.php/Information_and_communication_service statistics - NACE_Rev. 2.
} 
elasticity. Changes in consumer prices should capture consumer-market effects of VAT rate changes that explain changes in output because of a lower expected surplus if firms bear part of the consumption tax burden. Any direct effect of VAT on reported sales should thus be attributable to firms' consumption tax response. The positive and significant coefficient on Inflation suggests that an increase in overall price levels also inflates sales.

Consistent with our first hypothesis, we find a statistically significant and negative association of service affiliates' reported sales and value-added tax rates across all specifications. In our preferred specification (column (3)), we also control for the CIT rate and the coefficient estimate of the VAT rate is significant at the $1 \%$ level. The result indicates that a one percentage point increase in the VAT rate is associated with a reduction in affiliates' reported sales of 0.52 percent. In column (4), we test for a differential sales reporting behavior of foreign-owned firms by including the interaction of VAT and CIT with Multi. We find that firms' sales response to VAT is attenuated for firms with a foreign parent indicating that multinationals bear less of local taxes in line with recent evidence on investments and consumption taxes (Jacob et al. 2018). ${ }^{37}$ Interestingly, the significantly negative effect of the CIT rate on reported sales is driven by foreign-owned firms, which suggests that these MNEs anticipate a higher income tax burden (or a higher cost of shifting profits out of the affiliate) when reporting higher sales. ${ }^{38}$

[Insert Table 5 about here]

\section{VAT Planning by Digital Firms}

Column (5) of Table 5 reports results of our first test exploring the mechanisms of the effect of VAT on output of digital firms. The institutional background in the European Union provided the opportunity to engage in consumption tax planning through reporting sales in locations with lower VAT rates. One of the major characteristics of digital service providers is the flexibility of the business models (Barrett et al. 2015), which is enabled by technology and digital platforms through which such businesses distribute their services (Amit and Zott 2001). Digital service firms (e.g. online gambling or streaming platforms) are particularly flexible in their way of accessing markets via the internet without having a physical presence in each country ${ }^{39}$ (Cockfield 2002, p. 607; Agrawal and Fox 2017, European Commission 2017b) and should

\footnotetext{
${ }^{37}$ The coefficients are jointly significant $(p<0.01$ ), while the sum of the coefficients is significant only at the $10 \%$ level $(\mathrm{p}=0.101)$.

${ }^{38}$ The coefficients are jointly significant $(\mathrm{p}<0.01)$ and the sum of the coefficients $(-0.3096)$ is significant as well $(\mathrm{p}<0.01)$.

${ }^{39}$ The distribution of such services, i.e. the transportation of information goods, is nearly cost-less and is independent of the consumer's location such that providers are flexible in choosing the location of servers and other resources (Petruzzi and Buriak 2018).
} 
thus be capable of exploiting opportunities of VAT planning. With digital services being taxable in the origin country, VAT can be a potential competitive factor ${ }^{40}$ since digital service providers can realize higher after-VAT sales and profits when reporting sales in jurisdictions with a lower VAT rate (Lamensch 2017, p. 138). Fearing unfair competition stemming from inadequate VAT collection, European policy makers are concerned especially given the increasing digital services market in the $\mathrm{B} 2 \mathrm{C}$ segment, and have changed the provisions. ${ }^{41}$ While the destination principle also applies to digital services provided to private consumers in the EU since 2015 and thus repeals the differential tax incentive, enforcement of the new regulation and hence the collection of the VAT on digital services is considered insufficient. ${ }^{42}$

We use an indicator variable Digital equal to one if the affiliate is active in one of the digital service industry segments, i.e. industries that are characterized by non-physical, electronic service activities that are likely to be provided in the B2C sector. Digital B2C services include online publishing services such as e-books, online games, online gambling, web portals and music and video streaming or other content downloads. We thereby focus on NACE codes within information and communications services (NACE 58-63), renting of videos and tapes (NACE 7722), gambling and betting activities (9200) and other services that are likely to be provided via the internet (see Table 15 in the Online Appendix). ${ }^{43}$

\footnotetext{
${ }^{40}$ Although the VAT is an item in transit and, thus, does not appear on a firm's financial statement, the competitive advantage of VAT planning through sales reporting in low VAT countries is twofold. On the one hand, firms can charge lower gross consumers prices (Lamensch 2017, p. 138) while still generating the same net revenue. On the other hand, equal gross prices can be charged while generating higher net sales (Christensen et al. 2001; Hoopes et al. 2016). See Figure 4 in the Online Appendix for a simple calculation of the competitive advantage of crossborder digital over domestic digital service providers.

${ }^{41}$ European Commission (2014), p. 32. The unbalanced value-added taxation contributed to an estimated VAT gap of EUR 170 billion in 2013 (European Parliament 2016, p. 67). The European Commission also estimates that EUR 5 billion of VAT revenues are lost each year due to non-compliance on cross-border online sales (European Commission 2016). The Commissioner responsible for Taxation and Customs László Kovács noted: "I am content that the change in the rules on the place of supply of services will ensure a more even playing field for businesses supplying services throughout the Community. This is particularly true of services which can be supplied at a distance where, as a result of current rules, businesses have been locating in countries with lower VAT rates. As a result, Member States have seen their revenues eroded." The provisions "[...] aimed at changing the rules on VAT so as to ensure that VAT on services accrues to the country where consumption occurs, and to prevent distortions of competition between Member States operating different VAT rates". (European Commission 2008).

42 Agrawal and Fox (2017); Lamensch (2017); Bal (2015), p. 251; OECD (2015); Waerzeggers (2015), p. 138. Also see the annual report of the German Supreme Audit Institution for a critique on the allegedly dysfunctional control mechanisms (Bundesrechnungshof 2015, item 82).

${ }^{43}$ Manual screening of this sample revealed that we cover prominent affiliates of MNEs that offer digital services such as video streaming, gaming, and online gambling or running online platforms such as search engines and marketplaces. According to the industry classification used in this paper, approximately 9 percent of the service provider affiliates in our sample offer digital services and thus generate sales through online channels.
} 
We find a significantly stronger effect for the subset of digital service providers. ${ }^{44}$ Given a statistically significant coefficient of around -0.84 on the interaction term, the negative association between reported sales and the VAT more than doubles for affiliates providing digital services. A one percentage point increase in VAT rates is associated with a decrease in service affiliates' reported sales of around 1.66 percent. These findings are consistent with the expectation that affiliates of digital service providers have a strong incentive to report sales in low VAT rate countries by exploiting the planning opportunities stemming from differentials in consumption taxation. ${ }^{45}$

\section{Cross-sectional Tests: Industries}

Next, we investigate the heterogeneity in the consumption tax response across firms. In these cross-sectional tests, we employ a more stringent estimation approach using country-year fixed effects to control for unobserved variation in economic conditions or policies at the countrylevel that may be correlated with VAT changes. Using this econometric approach, we can only estimate the coefficient on the interaction between cross-sectional industry indicators and the $V A T$ rate. Resorting to the firm fixed effects structure as in equation (1), however, yields comparable results suggesting that our baseline specification successfully controls for unobserved variation in economic conditions and regulatory policies across countries. Results of estimating equation (1) including industry indicators interacted with $V A T$ and using country-year fixed effects instead of only controlling for GDP are reported in Table $6 .{ }^{46}$ As a baseline, we report the average affect excluding industry interactions in column (1) of Table 6.

We expect firms of four specific sub-categories to exhibit different responses depending on the impact of VAT on firms' cash flows and profitability. First, we again examine firms active in the digital services sector and confirm the results from our main analysis that digital service affiliates' sales are more responsive to VAT (column (2) of Table 6). Second, we classify affiliates in the non-digital B2C services sector that are presumably highly exposed to end-consumers and could face a substantial part of the VAT burden falling on them in case end-consumers are price-sensitive. Further, those affiliates are always liable to VAT in the country of their

\footnotetext{
${ }^{44}$ The coefficients are jointly significant $(p<0.01)$ and the sum of the coefficients $(-1.6622)$ is significant as well $(\mathrm{p}<0.01)$.

${ }^{45}$ The findings relate to the analysis of newspaper articles on U.S. firms by Agrawal and Fox (2017) finding that digital firms have reduced both VAT and CIT liabilities by reporting tax bases in low tax countries. Fox et al. 2014 document that companies in the online sector actively avoid consumption taxes in the U.S. market.

${ }^{46}$ With this specification, we can only estimate the coefficient on the interaction between the cross-sectional variable and VAT.
} 
incorporation (origin principle) which provides another reason why they should be more sensitive to VAT changes in their country. We denote those B2C affiliates by B2C_non-digital. Results are reported in column (3) of Table 6 and show that B2C firms react more negatively to VAT rate increases consistent with our expectation.

We then create proxies for affiliates providing services primarily intra-MNE and in the B2B sector and argue that these firms should respond less to consumption taxes. We do expect no VAT effect on output for B2B service providers or intra-group service units since any VAT payment is always refunded at the service-receiving firm level and, thus, does not translate into an ultimate financial burden. Technically, any consumer of a B2B service receives a VAT input credit and the VAT payment on that sale, both to external B2B consumers or to another firm of the same MNE, does not translate into an ultimate financial burden although the liability to remit VAT by the vendor constitutes a negative cash-flow effect as it is a significant cashoutflow. $^{47}$

However, Rozema (2018) argues that the principle of the consumption tax incidence may be extended to firms along the B2B supply chain, where market power among the agents determines the relative burden. ${ }^{48}$ Applying this to our example of company B in Figure 2 may look the following. Carrying part of the VAT burden means that company B is less profitable and consequently will either reduce output or try to reduce its input costs. Reducing the input costs may be possible either by changing production factors or by further passing on the VAT burden. That is, company B could force a lower price for its input materials it receives from company A, which depends on the relative market power compared to company A. Ultimately, the burden would be passed on to the B2B retailer company A. B2B service affiliates are classified based on their industry classification including agents of sale, wholesale, transportation of freight and storage, among other (NACE segments 46, 49, 50, 52, 77 (except 7722), 78, 81, and 82), and are denoted by $B 2 B$. Column (4) of Table 6 presents the results for B2B service affiliates. Consistent with our expectation, the effect of the VAT rate on these firms' sales is close to zero for this group of firms.

\footnotetext{
${ }^{47}$ Van de Leur (2017).

${ }^{48} \mathrm{He}$ investigates how the burden of consumption taxes is shared between upstream and downstream firms considering cigarette wholesale prices and finds that downstream firms selling the cigarettes bear a smaller portion of the firm share of the tax burden.
} 
If our sample firms offer intra-group services to another affiliate of the same MNE their reported sales should not be affected by VAT. ${ }^{49}$ We proxy for intracompany sales in our analysis to test whether such firms respond to VAT changes given the underlying mechanisms of tax incidence or strategic planning. We derive a proxy for intra-group service sales using information on the parent firm. We assume affiliates provide intra-group services if the parent firm is a manufacturing firm, i.e. if the ultimate parent is not classified as service provider itself nor as a holding company, and denote these affiliates by Intrafirm. ${ }^{50}$ Consistent with VAT on these services being refunded within the same MNE group, Column (5) of Table 6 finds an even positive coefficient on the interaction between Intrafirm and VAT, which might hint at the B2B sector becoming relatively more attractive when consumption taxes decrease firm profits in the $\mathrm{B} 2 \mathrm{C}$ sector.

Taken together, the results from the cross-sectional analyses support our hypothesis on firms' output being negatively affected by consumption taxes and the mechanisms underlying this behaviour (that is, tax incidence and consumption tax planning). Our baseline result of a VAT semi-elasticity of around 0.5 might actually be the lower bound of the true effect for service firms for two reasons. First, the baseline results capture B2B and intra-group sales that, in isolation, exhibit no response to VAT changes. Second, in case B2C services are offered free-ofcharge and sales are generated by other B2B transactions such as advertisements (i.e. like in the Google business model), we again would include B2B sales in our estimations for which VAT is not an ultimate financial disadvantage. Thus, these concerns should be a bias against finding significant results regarding the association of VAT and reported sales based on the baseline specification.

\section{[Insert Table 6 about here]}

\section{Cross-sectional Tests: Industries and Market Share}

Theory suggests that consumption tax incidence depends on the relative elasticity of supply and demand. The consumption tax responsiveness may thus vary across firms that face different levels of the elasticity of demand. To test this phenomenon, we rerun our cross-sectional tests based on the industry interactions and include a proxy for demand elasticity. We use a firm's

\footnotetext{
${ }^{49}$ There are two reasons. First, such a transaction constitutes a B2B transaction through which the buyer is granted an input tax deduction for the VAT remitted by the seller. Second, in many countries a group of companies can apply for joint filing through which only sales to external parties are liable to VAT.

${ }^{50}$ Examples of affiliates providing intra-group services include e.g. Mercedes-Benz G GMBH (AT), whose parent is classified as manufacturer of motor vehicles (NACE 2910) and Newell Rubbermaid UK LIMITED (GB), whose parent is classified as manufacturer of plastic products (NACE 2229).
} 
share of total assets in total industry assets as a proxy. ${ }^{51}$ We construct an indicator variable, Highassetshare, equal to one if a firm's share of total assets in total assets of the industry using 2-digit NACE codes is above the highest quartile of the asset share distribution by country and year. Similar to Jacob et al. (2018), who use a firm's size to proxy for demand elasticity, we argue that a firm's share of total assets can be a proxy for its market share and thereby for the size of a firm's output market and its market power. Firms with a higher market share may act as price setters and face less elastic demand. Results are reported in Table 7.

The average effect excluding industry interactions is reported in column (1) of Table 7. We find that the negative effect of consumption taxes on firms' reported sales is attenuated for firms with a relatively high market share consistent with those firms facing less elastic demand (Jacob et al. 2018). The results in columns (2) to (5) suggest that the overall effects for the different industries are comparable to our findings of the industry-cross-sections from Table 6 . In contrast to the overall effect of the average sample firm, we find that digital service firms and B2C firms are more responsive to VAT if they have a high market share (significant and negative coefficient on the triple interaction). We interpret this result as evidence for a bigger opportunity to gain a competitive advantage from engaging in consumption tax planning through sales reporting given their bigger size (and thus, sales). These firms have larger opportunities to exploit the origin principle, i.e. report sales at affiliates that face relatively lower VAT rates. The group of intra-group service firms does not show any differential behavior, which is consistent with these firms not being affected by consumption taxes given they are not engaging in external sales. The significant and positive coefficient for B2B firms shows that part of the overall positive response of this industry is driven by those B2B firms with a high market share. This also supports the argument that market power among the agents in the supply chain does matter.

[Insert Table 7 about here]

\section{Additional Tests: Group-level Analysis}

We employ a separate test to corroborate that our findings are driven by MNE firms' consumption tax planning considerations in terms of exploiting the origin principle (digital and B2C firms) and accounting for the incidence of the tax burden (all firms). We replace the dependent variable of the firm-level analysis by the aggregate, group-wide sales. LogGroupsales is the sum of reported sales of all affiliates in the sample that belong to the same MNE in a given

\footnotetext{
${ }^{51}$ Previous studies have used a firm's profit margin to approximate its position concerning demand elasticity (Lerner 1934; Aghion et al. 2005; Kubick et al. 2015; Jacob et al. 2018). Since we examine how consumption taxes affect a firm's output measured by sales, a variable such as profit margin may create concerns of endogeneity, so we refrain from using it in our analyses.
} 
year. For this analysis, we restrict the sample to firm-year observations for which we observe at least two affiliates belonging to the same MNE. ${ }^{52}$ The dummy variable Intl distinguishes between domestic groups and MNEs within the sample that are incorporated in different countries.

If firms respond to changing incentives from VAT, they might shift reported sales from one country to another country if they have this arbitrage opportunity. Two forces can drive such behavior. First, selling to customers in a different country becomes relatively more profitable if the VAT rate increases in a given country where the affiliate selling to local customers bears part of an increased VAT rate. Second, digital and B2C firms might exploit the origin principle in response to a VAT rate change in a given country and sell to the same customers from a different location with a more attractive VAT rate. In both cases, we would expect overall group sales to remain constant for firms with these international consumption tax opportunities. Domestic service groups, however, are affected by the changes in VAT rate with no (short-term) reporting strategies other than adjusting output in the opposite direction of the VAT change.

We use LogGroupsales as the dependent variable and augment equation (1) by interacting VAT with Intl. The baseline results (column (1) of Table 8) confirm our main results and show that also the group-wide sales negatively respond to VAT rate increases. The highly significant and positive coefficient on the interaction term of VAT and Intl is consistent with service MNEs engaging in consumption tax planning. This result is consistent with our finding that multinationals bear local taxes to a lesser extent (column (4) of Table 5) and suggests that MNEs increase output in locations with relatively lower VAT rates to a greater extent that they decrease output in locations where VAT rates increase.

We further extend this analysis and account for a differential behavior of firms within the four industries (Digital, B2C_non-digital, Intrafirm, and B2B). Again, we employ a more stringent estimation approach and use country-year fixed effects. Column (2) confirms our result for the baseline effect that aggregated sales of international groups do not change or even overcompensate in response to VAT rate changes. Columns (3) to (6) report the results. We can only document a differential behavior for the group of digital service firms. The strong negative reaction of digital service firms' sales to VAT rate changes is still present but attenuated given a significant and positive coefficient on the triple-interaction term. The latter result corroborates

\footnotetext{
${ }^{52}$ These estimations are therefore based on a smaller sample since we require multinational groups to have domestic groups as counterfactuals. Other firm-year observations of our base sample belong to groups (see the sample selection process) but other group firms are not part of the sample.
} 
the finding that digital firms shift reported sales to a firm located in another country when the VAT rate in the market location increases.

[Insert Table 8 about here]

\section{Additional Tests: Consumption Tax Planning and Profit Shifting Incentives}

In a preliminary test of whether consumption tax planning and corporate income tax-motivated profit shifting behavior are interrelated, we make use of the staggered implementation of VAT rate changes in our European sample over the period 2007 to 2015 to investigate whether firms anticipate the effect that consumption tax planning has on the corporate income tax base. Sophisticated corporate tax planners might be aware of the fact that consumption tax planning places a constraint on exploiting profit shifting opportunities given that reported sales directly map into pre-tax profits. In particular, they might evaluate the benefits of responding to valueadded taxes via reporting sales against the potential costs of subsequent income taxation driven by the applicable CIT rate. If this is the case, an increase in the VAT rate should not invoke a negative sales response if the level of (subsequent) income taxation is relatively low. Accordingly, firms might be particularly active in consumption tax planning if the associated effect on pre-tax income is congruent with the goal of income tax minimization.

We modify equation (1) and replace the continuous measure VAT by indicator variables for tax rate changes, VATminus (VATplus) taking on the value of one if an affiliate experiences a VAT rate cut (increase) in the respective year and zero otherwise. We then interact these variables separately with an indicator for being located in a country with a low CIT rate, LowCIT. The indicator is equal to one if the CIT rate is below median of the sample or below $21 \%$. This approach allows us to analyze whether firms' sales response to VAT cuts and increases is asymmetric and whether it depends on the CIT rate, which determines the (subsequent) level of profit taxation. Figure 5 in the Online Appendix shows that we exploit substantial variation since our sample consists of countries with both favorable (e.g. Bulgaria and Czech Republic) or unfavorable (e.g. Portugal) CIT and VAT rates relative to the sample mean, and countries with either a relatively high CIT and low VAT rate (e.g. Spain and Germany) or vice versa (e.g. Hungary). Figure 6 further illustrates the variation exemplarily for the year 2015.

We report results in Table 9. In column (1), we interact the indicators for VAT cuts and increases with the indicator for a CIT rate below median and find a highly significant and positive coefficient on the interaction term of VATplus and LowCIT suggesting that firms' reaction to VAT increases is attenuated when the CIT rate is sufficiently low. This suggests that affiliates 
in countries with a CIT rate below the median over the entire sample period (31.4 percent) do not negatively react to increases of the VAT rate when reporting sales. The coefficient on the interaction of VATminus and LowCIT cannot be reported in column (1) since VAT rate decreases are rare (only about 2,800 observations) and hardly occur for countries in our sample with a CIT rate below median. In column (2), we find similar results when LowCIT denotes that the CIT is below 21\%. Firms' negative response to VAT rate increases is attenuated (even overcompensated) when the CIT rate is below $21 \%$. We also find that the positive response to VAT cuts is generally stronger and find no differential effect for the case that the CIT rate is low. These results suggest that the sales response to VAT rate increases is contingent on the CIT rate being sufficiently high.

[Insert Table 9 about here]

\subsection{Profit Shifting in the Presence of Consumption Taxes}

\section{Profit Shifting Behavior and Consumption Taxes}

Having established that firms' output in terms of reported sales is sensitive to consumption taxes, we integrate this finding in the analysis of income tax-motivated profit shifting. Table 10 reports the results of estimating the model of service affiliates' pre-tax profit reporting response to changes of the CIT rate. All specifications include firm and year fixed effects. We first replicate the baseline model established in prior literature (column (1)). In general, the magnitude of profit shifting across all specifications is consistent with earlier findings implying that profit shifting behavior in the service sector is similar to that of firms in other industries. ${ }^{53}$ For service providers, a one percentage point increase in CIT rates is associated with a decline in pre-tax profits of around 0.47 percent on average. When we also control for the VAT rate, we find a significant and negative association of pre-tax profits and the value-added tax rate (column (2)) suggesting that planning for consumption taxes affects reported pre-tax profits given sales are highly correlated with reported pre-tax profits.

[Insert Table 10 about here]

The results of our analysis so far suggest that firms react to VAT rate changes in their sales reporting behavior and that firms consider income tax-related costs when planning on consump-

\footnotetext{
${ }^{53}$ Huizinga and Laeven (2008) estimate a coefficient of -0.595 in a similar specification, analogously Blouin et al. (2018) estimate -0.542. Consistently, coefficients on LogPexp, LogAssets and $\log G D P$ are all positive and significant.
} 
tion taxes. If the two tax policy parameters, the VAT and CIT rate, gauge conflicting tax management objectives exploiting a VAT rate cut through reporting higher sales could result in a cost due to a higher income tax burden or a higher cost of profit shifting. If, for example, a country's tax system is characterized by a low VAT and a high CIT rate, reporting higher sales in response to the low VAT rate requires profit shifting to be employed in a more aggressive manner on the cost side of an intra-group transaction in order to minimize pre-tax profits in the same country.

We investigate the dependence of profit shifting on the level of consumption tax responsiveness by including our measure of firm-specific VAT sensitivity ${ }^{54}$ with regards to sales reporting and test whether the respective variation across firms explains differences in profit shifting behavior. The variable $\triangle V A T$ gauges the affiliate-specific intensity of consumption tax planning with positive increasing values indicating a stronger consumption tax response. Columns (3) and (4) report results of our main tests of our second hypothesis (equation (2)). We report a significant positive coefficient on the interaction term of $\triangle V A T$ and $C I T$ in both specifications suggesting that profit shifting is attenuated when firms respond to the VAT rate. We plot the marginal effects of the CIT rate on reported pre-tax profits in Figure 3 to allow for a direct interpretation depending on the level of $\triangle V A T$. We find that only firms that do not negatively react to consumption taxes (negative values for $\triangle V A T$ ) engage in profit shifting (i.e. negative and statistically significant effect of CIT). To provide an additional test, we also include the interaction between $\triangle V A T$ and the VAT rate in column (4) and find a significantly positive coefficient consistent with the negative effect of VAT already being captured for the subgroup of firms with higher values of $\triangle V A T$.

\section{[Insert Figure 3 about here]}

Overall, these results are novel to the profit shifting literature and suggest that differential profit shifting behavior can be explained by a firm's consumption tax responsiveness. These findings imply that firms do not jointly minimize the tax burden from consumption and profit taxes but that managing the possible consumption tax burden in the first place constrains profit shifting.

\footnotetext{
${ }^{54}$ We construct this measure by running a regression of sales on the CIT and VAT rates and the control variables as in specification (3) of Table 5 and interact the VAT rate with the vector of firm fixed effects. The point estimates on interaction terms yield the firm-specific VAT sensitivities with regards to sales reporting. We multiply the values by minus one and winsorize them at 1 and 99 percent. We use the high dimensional fixed effects regression estimator by Correia (2016). Given the large number of affiliates in the sample, the Stata-command REGHDFE is applied. The command drops singleton groups, i.e. in our case firm fixed effects with only one observation in the sample period, to avoid overstating statistical significance. Dropping singletons results in a slightly smaller sample of 299,901 affiliate-years. Table 16 in the Appendix reports results of using this estimation approach with and without interacting the VAT rate with firm fixed effects. We find that estimates are generally in line with our fixed effects regression using the standard approach (Table 5).
} 
Our findings on the relationship between consumption tax planning and income shifting are consistent with those of Blouin et al. (2018) using a different setting to show that profit shifting behavior is attenuated when custom duties cannot jointly be minimized via transfer pricing.

\section{Cross-sectional Tests: Industries}

The recent public debate and anecdotal evidence suggest that firms in the digital economy engage in particularly aggressive profit shifting (OECD 2015, European Commission 2014 ${ }^{55}$ ). Empirical studies document that MNEs report lower (higher) profits in high-tax (low-tax) affiliates if they have the opportunity to employ transfer pricing strategies based on the exploitation of intellectual property (e.g. Harris 1993, Grubert 2003, Beer and Loeprick 2015). Further, intangible (and thus more mobile) assets are located in tax favorable jurisdictions to facilitate tax planning (e.g. Griffith et al. 2014). Primary value drivers of digital business models are the use of internet technologies, self-developed software and human capital-related organizational assets (Brynjolfsson and McAfee 2014) that are hardly captured by publicly available financial information. ${ }^{56}$ Apart from the evidence in Klassen et al. (2014), which is limited to the U.S. ecommerce sector, we do not know whether firms in the digital sector of the economy are particularly active tax planners. We thus consider this an empirical question.

In cross-sectional tests, we test for differential profit shifting behavior of service affiliates in the four industries as defined above. For these tests, we augment equation (2) by interacting the respective industry indicators (Digital, B2C_non-digital, Intrafirm, and B2B) with the CIT and the interaction term of the $C I T$ and $\triangle V A T$. Similar to our cross-sectional analyses on consumption taxes and firms' output, we employ country-year fixed effects to control for any economic conditions that are unobserved but possibly correlated with tax policy. Table 11 reports the regression results. We do not find evidence for a significantly different effect of the CIT rate on reported profits in case of digital service providers. We can, however, show that the attenuation effect of the consumption tax sensitivity is somewhat stronger for digital service firms given a significant (10\%-level) and positive coefficient on the triple-interaction term. However,

\footnotetext{
${ }^{55}$ See e.g. Netflix paying only little corporation tax in the UK (The Guardian (online) 13 October 2016, available at https://www.theguardian.com/business/2016/oct/13/netflix-uk-corporation-tax). The finance ministers of several European Union (EU) countries recently claim that the current tax system is flawed, arguing MNEs pay only little tax in countries where they exploit consumer markets and rely on the local infrastructure. The Wall Street Journal (online) 21 September 2017, available at: https:/www.wsj.com/articles/eu-preps-tax-crackdown-on-silicon-valley-1505988538. Potential solutions to address the issue include mechanisms to tax MNEs based on the location of consumption rather than on book profits. Discussed instruments are an equalization tax on digital sales or extended withholding taxes. In a recent initiative, the finance ministers of the EU state that "[being] able to appropriately tax the companies operating in the digital economy is a major challenge for the European Union" and that effective solutions need to be employed quickly (EU2017 2017a; EU2017 2017b).

${ }^{56}$ Forms of intellectual property measured in prior empirical studies are mostly intangible assets, R\&D, and patents and hence probably do not account for different forms of value drivers in digital business models.
} 
the overall sum of the coefficients is not significant. Future research could address whether firms in the digital economy exploit tax planning channels that we cannot measure with the approach of estimating a standard production function.

We document that profit shifting behavior of B2C service firms is comparable to that of digital service firms: the effect of the CIT rate on reported pre-tax profits is strongly attenuated for these firms (column (3)). For our sub-group of intra-group service providers, we do not find any differential behavior (column (4)). For B2B service affiliates, in contrast, we find that profit shifting behavior is not attenuated if firms are VAT sensitive. While the coefficient on the interaction term of $C I T$ and $\triangle V A T$ is significant and positive, this attenuation effect is eliminated for the $\mathrm{B} 2 \mathrm{~B}$ firms given the significant and negative coefficient on the triple interaction $\left(B 2 B^{*} C I T^{*} \triangle V A T\right)$.

Overall, these cross-sectional results are consistent with the industry-specific findings on consumption tax planning. They indicate that firms providing intra-group and B2B services have sufficient leeway in engaging in profit shifting even if they are sensitive to VAT changes. Their sensitivity to VAT changes as reported in Table 6, however, is much lower and thus their behavior towards consumption taxes is less restrictive for engaging in profit shifting. In sum, the results in Table 10 and Table 11 support our hypothesis that the negative association between reported pre-tax profits and income tax rates is attenuated for firms with a higher consumption tax rate sensitivity.

[Insert Table 11 about here]

\section{Cross-sectional Tests: Interest Expense}

We additionally test whether firms resort to a different profit shifting channel when manipulating pre-tax profits for income tax purposes is constrained by consumption tax considerations. So far, we have effectively examined transfer pricing of intra-group trade (goods and services transactions) as one of the major channels of profit shifting since EBIT (or LogEbit) as the dependent variable captures such transfer pricing manipulations (e.g. Maffini and Mokkas 2011, Heckemeyer and Overesch 2017). In addition to this channel, MNEs can use intra-group debt financing as an additional profit shifting channel. Heckemeyer and Overesch (2017) find that this financing channel accounts for around one third of income tax-motivated pre-tax profit shifting. 
If a firm's profit shifting behavior is restricted by its response to consumption taxes, the firm might increase intrafirm debt financing in order to optimize its income tax position. We operationalize this mechanism by estimating equation (2) with two different dependent variables. First, we use return on assets $(R o A)$, measured as earnings before interest and taxes over total assets, as an alternative dependent variable. Second, we compare these results to an estimation of equation (2) using interest expense scaled by total assets (IntExpoA) as the dependent variable. IntExpoA is our measure to gauge the debt financing behavior of firms. We expect a positive coefficient on CIT since interest expenses should increase in response to CIT rate increases in order to shift pre-tax profits out of the respective jurisdiction (Grubert 1998, Desai et al. 2004).

Results are presented in Table 12. We confirm our main finding on the relation of profit shifting and consumption tax sensitivity in column (1). The coefficient on the baseline effect of the CIT rate on $R o A$ is significant and negative and the interaction term of the CIT and $\triangle V A T$ is significant and positive indicating the attenuation effect. When examining IntExpoA as the dependent variable, we find results consistent with our expectation (column (2)). The baseline effect of the CIT rate suggests that firms increase interest expenses when CIT rates increase. Given the positive and significant coefficient on the interaction term between $C I T$ and $\triangle V A T$, we find that this relationship is more pronounced when firms are more sensitive to VAT. This result indicates that firms engage in profit shifting behavior via debt financing to a greater extent when the other channel of profit shifting, transfer pricing manipulation with respect to intra-group trade, is constrained by consumption tax considerations. We can confirm the results after controlling for country-year fixed effects (columns (3) and (4)). Lastly, we augment our regression equation and interact the $C I T$ and $\triangle V A T$ interaction by InterestLimit, an indicator variable equal to one if there exists any regulation limiting the deductibility of interest expenses in the affiliate's country. We do not find any differential effect for these affiliates (column (5)) and infer that interest deductibility limitations do not inhibit this profit shifting channel for our sample firms.

[Insert Table 12 about here]

\subsection{Robustness Tests}

We conduct several untabulated robustness tests to validate our results. We run a firm-fixed effects and random effects model clustering standard errors on the country level for the sales reporting and profit shifting analyses and results remain robust. ${ }^{57}$ We also find very similar

\footnotetext{
${ }^{57} \mathrm{~A}$ p-value of below 0.0000 in the Hausman test suggests the fixed-effects model is appropriate.
} 
results when running a robust regression suggesting that outliers in our sample do not drive the results (De Simone 2016).

Results across all analyses are robust to controlling for a different production function of digital service affiliates when we run a fully interacted model (Digital interacted with other explanatory variables in the production function). In further robustness checks, we exclude observations from single countries for which observations are heavily weighted due to superior data coverage (France and Spain) and obtain robust results.

We conduct a further cross-sectional test and limit the sample to affiliates that belong to multinational groups with at least three affiliated companies. ${ }^{58}$ Consistent with this subsample of firms having greater tax planning opportunities, we find slightly larger effects of the CIT rate on reported pre-tax profits. Further, results hold when replacing personnel expenses by the number of employees and winsorizing financial firm data at the 1 and 99 percent level.

Our results across all analyses are robust to including GDP-growth to account for market potential. We also argue that GDP-growth accounts for potential changes in demand that might be correlated with VAT rate changes and firms' output (sales). These results suggest that the response of reported sales to VAT rates is not driven by simultaneous changes in demand and serve as robustness additionally to including consumer price levels and inflation rates as well as our stringent empirical approach employing country-year fixed effects.

\section{Conclusion}

This paper examines the effect of consumption taxes on firm-level output and whether reporting sales in response to consumption taxes explains cross-sectional variation in income tax-motivated profit shifting. We study service firms who have some leeway to plan on consumption and income taxes and exploit the European setting with plausibly exogenous changes in valueadded and corporate income tax rates. We estimate that firms, on average, reduce reported sales by 0.5 percent if VAT rates increase by one percentage point. We control for country-specific contemporaneous trends that might explain tax policy and output levels. Several cross-sectional tests based on firms' industry classification and aggregate sales of a firm's business group show that two channels drive consumption tax planning. First, firms bearing part of the tax burden reduce output due to lower expected after-tax profits. Second, firms with leeway over where to report sales for VAT purposes shift sales in response to the relative attractiveness of a country's

\footnotetext{
${ }^{58}$ This analysis is contingent on data availability and accuracy provided by the Amadeus database at the point of time of data extraction.
} 
VAT rate. Consistent with recent evidence (Jacob et al. 2018), the magnitude of the effects depends on firms' relative size as a proxy for its ability to set prices.

We then show that, on average, firms do not engage in income tax-motivated profit shifting if they exhibit a negative relationship between reported sales and VAT consistent with consumption tax planning placing a constraint on manipulating transfer prices to reduce the global income tax burden. However, these firms more actively use debt financing to reduce pre-tax income in response to income tax rate increases. Our findings thereby contribute to the literature on the effect of taxes on corporate decisions and corporate tax planning behavior. We complement Jacob et al. (2018) by directly showing that firms respond to consumption taxes. Along the lines of Blouin et al. (2018), we offer a novel explanation why some firms employ more aggressive profit shifting strategies than others. In particular, we are the first to study how consumption and corporate income taxes interrelate and conclude that corporate tax planners consider multiple taxes as a cost to the business.

Our results have several implications for tax policy design since understanding the interplay of direct and indirect taxes is important to evaluate tax policy. Consumption taxes, in particular, are a major source of tax revenue, an important element in competition among jurisdictions to attract remote firms in the digital sector, and can lead to inefficiencies in corporate decisions. First, our findings strongly suggest that consumption taxes affect corporate behavior. That is, firms reduce their reported output in response to VAT rate increases. Second, we provide evidence that firms operating in the digital economy indeed exploit tax planning opportunities. However, we highlight that circumventing consumption tax burdens seems to dominate income tax-motivated profit shifting. This insight potentially speaks to the estimated gap in VAT collection in the EU. It further questions the practical ability of purely consumption-based tax systems to mitigate tax avoidance and economic distortions in a globalized and digital economy. Third, policy makers should carefully evaluate whether to follow the current trend of decreasing CIT rates and increasing VAT rates when assessing the impact on corporate decisions and tax revenue (Clausing 2009).

Although we rely on a large representative sample and provide cross-sectional results in line with economic theory, we acknowledge that we cannot directly observe whether firms exclusively generate sales in the designated sector and to what extent our sample affiliates engage in cross-border transactions, which is a condition for the ability to engage in international tax planning. Also, we do not observe the complete set of affiliates belonging to an MNE in our sample but focus on affiliates active in the service industry only. The economic magnitude of 
our results should thus be interpreted with caution. Another concern would be that an MNE's group structure and choice to locate affiliates in specific countries is not exogenous and might be driven by tax factors, among others. We argue that the potential sample selection bias should not be a concern since the formation of business groups is not responsive to the business environment in the short-term such as tax rate changes that we rely on for our inferences (Khanna and Yafeh 2005).

Overall, our findings add to the literature examining the interaction of consumption and income taxes and shed some first light on the tax planning behavior of firms in the digital economy. We further add to the income tax avoidance literature by showing that the extent and the channels of profit shifting are contingent on firms' responses to consumption tax incentives. Our results suggest that firms incorporate both incentives stemming from income and consumption tax regimes in their tax planning strategies. We thus consider the channels firms employ to account for the interactions of different tax incentives and to optimize on multiple taxes as well as firms' response to tax incentives in the digital economy interesting objects of future analysis. 


\section{References}

Aghion, P./Bloom N./Blundell R./Griffith R./Howitt P. (2005), Competition and innovation: An inverted U relationship, Quarterly Journal of Economics 120 (2), 701-728.

Agrawal, D. (2017), The Internet as a Tax Haven? The Effect of the Internet on Tax Competition, Working Paper, University of Kentucky.

Agrawal, D.R./Fox, W. F. (2017), Taxes in an E-Commerce Generation, International Tax and Public Finance 24(5), 903-926.

Alm, J./Sennoga, E./Skidmore, M. (2009), Perfect Competition, Urbanization, and Tax Incidence in the Retail Gasoline Market, Economic Inquiry 47 (1), 118-134.

Amit, R./Zott, C. (2001), Value Creation in E-business, Strategic Management Journal 22, 493-520.

Anderson, E. T./Fong, N. M./Simester, D. I./Tucker, C. E. (2010), How Sales Taxes Affect Customer and Firm Behavior: The Role of Search on the Internet, Journal of Marketing Research 47(2), 229-239.

Arnold, J. M./Brys, B./Heady, C./Johansson, A./Schwellnus, C./Vartia, L. (2011), Tax Policy for Economic Recovery and Growth, The Economic Journal 121 (550), F59-F80.

Atkinson, A. B./Stiglitz, J. E. (1976), The Design of Tax Structure: Direct Versus Indirect Taxation, Journal of Public Economics 6, 55-75.

Atkinson, A. B./Stiglitz, J. E. (1972), The Structure of Indirect Taxation and Economic Efficiency, Journal of Public Economics 1, 97-119.

Auerbach, A. J./Devereux, M. P./ Keen, M./Vella, J. (2017), International Tax Planning Under the Destination-Based Cash Flow Tax, Working Paper, University of Oxford.

Bal, A. (2017), EU VAT Proposals to Stimulate Electronic Commerce and Digital Publishing, International VAT Monitor March/April 2017, 132-136.

Bal, A. (2015), Taxation of Digital Supplies in the European Union and United States - What Can They Learn from Each Other?, European Taxation June 2015, 245-253.

Barrett, M./Davidson, E./Prabhu, J./Vargo, S. (2015), Service Innovation in the Digital Age: Key Contribution and Future Directions, MIS Quarterly 39 (1), 135-154.

Baugh, B./Ben-David, I./Park, H. (2014), The "Amazon Tax": Empirical Evidence from Amazon and Main Street Retailers, NBER Working Paper Series 20052.

Beer, S./Loeprick, J. (2015), Profit Shifting: Drivers of Transfer (Mis)Pricing and the Potential of Countermeasures, International Tax and Public Finance 22 (3), 426-451.

Besley, T. J./Rosen, H. S. (1999), Sales Taxes and Prices: An Empirical Analysis, National Tax Journal 52:157-178.

Blouin, J./Robinson, L./Seidman, J. (2018), Conflicting Transfer Pricing Incentives and the Role of Coordination, Contemporary Accounting Research 35(1), 87-116.

Bruce, D./Fox, W.F./Luna, L. (2015), E-Tailer Sales Tax Nexus and State Tax Policies, National Tax Journal 68(3S), 735-766.

Brynjolfsson, E./McAfee, A. (2014), The Second Machine Age, W. W. Norton. 
Brynjolfsson, E./Hitt L. M. (2003), Computing Productivity: Firm-Level Evidence, The Review of Economics and Statistics 85(4), 793-808.

Bundesrechnungshof (Supreme Audit Institution of the Federal Republic of Germany) (2015), Annual Report on Federal Financial Management, available at: https://www.bundesrechnungshof.de/en/veroeffentlichungen/annualreports/dateien/annual-report-2015.

Cardona, M./Kretschmer, T./Strobel, T. (2013), ICT and Productivity: Conclusions from the Empirical Literature, Information Economics and Policy 25, 109-125.

Chen, S./De Simone, L./Hanlon, M./Lester, R. (2017), The Effect of Innovation Box Regimes on Income Shifting and Real Activity, Working Paper No. 3453.

Christensen, K./Cline, R./Neubig, T. (2001), Total Corporate Taxation: "Hidden," Above-TheLine, Non-Income Taxes, National Tax Jounal 54 (3), 495-506.

Clausing, K. A. (2009), Multinational Firm tax Avoidance and Tax Policy, National Tax Journal 62 (4), 703-725.

Cockfield, A. J. (2002), The Law and Economics of Digital Taxation: Challenges to Traditional Tax Laws and Principles, Bulletin of International Bureau of Fiscal Documentation 56 (12), 606-619.

Correia, S. (2016), Linear Models with High-Dimensional Fixed Effects: An Efficient and Feasible Estimator. Working Paper.

Desai, M. A./Foley, C. F./Hines Jr, J. R. (2004), A Multinational Perspective on Capital Structure Choice and Internal Capital Markets, The Journal of Finance 59(6), 2451-2487.

Devereux, M. P./Vella, J. (2017), Implications of Digitalization for International Corporate Tax Reform, Working Paper, University of Oxford.

De Simone, L. (2016), Does a Common Set of Accounting Standards Affect Tax-Motivated Income Shifting for Multinational Firms?, Journal of Accounting and Economics 61, 145165.

De Simone, L./Klassen, K./Seidmann, J. (2017), Unprofitable Affiliates and Income Shifting Behavior, The Accounting Review 92(3), 11-136.

Dharmapala, D. (2014), What Do We Know about Base Erosion and Profit Shifting? A Review of the Empirical Literature, Fiscal Studies 35 (4), 421-448.

Dharmapala, D./Riedel, N. (2013), Corporate Taxes and the Location of Intangible Assets Within Multinational Firms, Journal of Public Economics 95, 691-707.

Dowd, T./Landefeld, P./Moore, A. (2017), Profit Shifting of U.S. Multinationals, Journal of Public Economics 148, 1-13.

Dyreng, S./Markle, K. (2016), The Effect of Financial Constraints on Income shifting by U.S. Multinationals, The Accounting Review 91(6), 1601-1627.

Dyreng, S./Maydew, E. (2018), Virtual Issue on Tax Research Published in the Journal of Accounting Research, Journal of Accounting Research Virtual Issue January 2018.

Einav, L./Knoepfle, D./Levin, J./Sundaresan, N. (2014), Sales Taxes and Internet Commerce, American Economic Review 104 (1), 1-26. 
Engelen, W. (2017), US Border Adjustment Tax, a New VAT in Town?, International VAT Monitor 28 (3), 201-202.

Ellison, G./Ellison, S. (2009), Tax Sensitivity and Home State Preferences in Internet Purchasing, American Economic Journal 1 (2), 53-71.

Ernst \& Young (2013), 2013 Global Transfer Pricing Survey.

EU 2017 (2017a), Presidency Issues Note 16 September 2017, available at: https://www.eu2017.ee/sites/default/files/201709/Ecofin\%20Informal WS\%20II digital\%20economy 15-16.Sept .17.pdf.

EU 2017 (2017b), Press Release for the Informal Meeting of Economic and Financial Affairs Ministers (ECOFIN) in Tallinn 15-16 September 2017, available at: https://www.eu2017.ee/news/press-releases/eu-finance-ministers-agreed-develop-newdigital-taxation-rules.

European Commission (2018a), Time to Establish a Modern, Fair and Efficient Taxation Standard for the Digital Economy, COM(2018) 146 final, 21 March 2018, available at https://ec.europa.eu/taxation_customs/sites/taxation/files/communication_fair_taxation_d igital_economy_21032018_en.pdf.

European Commission (2018b), Study and Reports on the VAT Gap in the EU-28 Member States: 2017 Final Report (TAXUD/2015/CC/131).

European Commission (2017a), Study and Reports on the VAT Gap in the EU-28 Member States: 2018 Final Report (TAXUD/2015/CC/131).

European Commission (2017b), A Fair and Efficient Tax System in the European Union for the Digital Single Market, $\operatorname{COM(2017)} 547$ final, 21 September 2017, available at https://ec.europa.eu/taxation customs/sites/taxation/files/1 en act part1 v10 en.pdf.

European Commission (2017c), Communication from the Commission to the European Parliament, the Council and the European Economic and Social Committee on the follow-up to the Action Plan on VAT - Towards a single EU VAT are - Time to decide, $\operatorname{COM}(2017) 566$ final, 4 October 2017, available at https://ec.europa.eu/taxation_customs/sites/taxation/files/communication_towards a single vat area en.pdf.

European Commission (2016), Fact Sheet, Modernising VAT for E-Commerce: Questions and Answers (1 Dec. 2016), MEMO/16/3746.

European Commission (2014), Report of the Commission Expert Group on Taxation of the Digital Economy, 28/05/2014.

European Commission (2008), Press Release IP/08/208, Brussels, 12 February 2008, available at http://europa.eu/rapid/press-release_IP-08-208_en.htm.

European Communities (2008), NACE Rev. 2, Statistical classification of economic activities in the European Community.

European Parliament (2016), Tax Challenges in the Digital Economy, available online at: http://www.europarl.europa.eu/RegData/etudes/STUD/2016/579002/IPOL_STU(2016)5 79002_EN.pdf. 
Eurostat (online), Information and communication service statistics, available at: http://ec.europa.eu/eurostat/statistics-explained/index.php/Information and communication service_statistics - NACE_Rev._2 (last accessed 12 February 2018).

Eurostat (2018a), Tax revenue statistics, available at: http://ec.europa.eu/eurostat/statisticsexplained/index.php/Tax revenue statistics\#Main tables (last accessed 11 October 2018).

Eurostat (2018b), Comparative price levels of consumer goods and services, available at: http://ec.europa.eu/eurostat/statistics-explained/index.php/Comparative_price_levels of consumer goods and services\#Data sources and availability (accessed March 2018).

Fox, W./Luna, L./Schaur, G. (2014), Destination Taxation and Evasion: Evidence from U.S. Inter-State Commodity Flows, Journal of Accounting and Economics 57, 43-57.

Fullerton, D./Metcalf, E. G. (2002), Handbook of Public Economics, North Holland, Vol.4, 1787-1872.

Goolsbee, A. (2000), In a World Without Borders: The Impact of Taxes on Internet Commerce, Quarterly ournal of Economics 115(2), 561-576.

Graetz, M.J. (2016), Should the U.S. Adopt a Value-Added Tax?, The Wall Street Journal (online) 28 February 2016, available at: https://www.wsj.com/articles/should-the-u-sadopt-a-value-added-tax-1456715703.

Griffith, R./Miller, H./O’Connell, M. (2014), Ownership of Intellectual Property and Corporate Taxation, Journal of Public Economics 112, 12-23.

Grubert, H. (2003), Intangible Income, Intercompany Transactions, Income Shifting, and the Choice of Location, National Tax Journal 56 (1), 221-242.

Grubert, H. (1998), Taxes and the division of foreign operating income among royalties, interest, dividends and retained earnings, Journal of Public Economics 68 (2), 269-290.

Grubert, H./Mutti, J. (1993), Taxes, Tariffs and Transfer Pricing in Multinational Corporate Decision Making, Review of Economics and Statistics 73, 285-293.

Hanlon, M./Heitzman, S. (2010), A Review of Tax Research, Journal of Accounting and Economics 50(2-3), 127-178.

Harding, M./Leibtag, E./Lovenheim, M. (2012), The Heterogeneous Geographic and Socioeconomic Incidence of Cigarette Taxes: Evidence from Nielsen Homescan Data, American Economic Journal: Economic Policy 4(4), 169-198.

Harris, D. G. (1993), The Impact of U.S. Tax Law Revision on Multinational Corporations' Capital Location and Income-Shifting Decisions, Journal of Accounting Research 31, 111 140.

Hebous, S./Johannesen N. (2016), At Your Service! The Role of Tax Havens in International Trade with Services, CESifo Working Paper Series No. 5414.

Heckemeyer, J./Overesch, M. (2017), Multinationals' Profit Response to Tax Differentials: Effect Size and Shifting Channels, Canadian Journal of Economics 50 (4), 965-994.

Heider, F./Ljungqvist, A. (2015), As Certain as Debt and Taxes: Estimating the Tax Sensitivity of Leverage from State Tax Changes, Journal of Financial Economics 118 (3), 684-712. 
Hellerstein, W. (2016), Taxing Remote Sales in the Digital Age: A Global Perspective, 65 American University Law Review, 1195-1239.

Hines, J./Rice, E. (1994), Fiscal Paradise: Foreign Tax Havens and American Business, Quarterly Journal of Economics 109, 149-181.

Hoopes, J./Thornock, J./Williams, B. (2016), Does Use Tax Evasion Provide a Competitive Advantage to E-Tailers?, National Tax Journal 69 (1), 133-168.

Huizinga, H./Laeven, L. (2008), International Profit Shifting Within Multinationals: A MultiCountry Perspective, Journal of Public Economics 92, 1164-1182.

Jacob, M./Michaely, R./Müller, M. A. (2018), Consumption Taxes and Corporate Investment, Review of Financial Studies, Forthcoming.

Keen, M./Lockwood, B. (2010), The Value Added Tax: Its Causes and Consequences, Journal of Development Economics 92, 138-151.

Kenkel, D. (2005), Are Alcohol Tax Hikes Fully Passed Through to Prices? Evidence from Alaska, The American Economic Review 95 (2), 273-277.

Keuschnigg, M. P./Devereux, M. P. (2013), The Arm's Length Principle and Distortions to Multinational Firm Organization, Journal of International Economics 89, 432-440.

Khanna, T./Yafeh, Y. (2005), Business Groups and Risk Sharing around the World, The Journal of Business, 78(19), 301-340.

Klassen, K./Laplante, S./Carnaghan, C. (2014), A Model of Multinational Income Shifting and an Application to Tax Planning with E-Commerce, Journal of the American Taxation Association 36(2), 27-53.

Klassen, K./Laplante, S. (2012), The Effect of Foreign Reinvestment and Financial Reporting Incentives on Cross-Jurisdiction Income shifting, Contemporary Accounting Research 29 (3), 928-955.

Kopczuk, W./Slemrod, J. (2006), Putting Firms into Optimal Tax Theory, The American Economic Review 96 (2), 130-134.

Kosonen, T. (2015), More and Cheaper Haircuts after VAT Cut? On the Efficiency and Incidence of Service Sector Consumption Taxes, Journal of Public Economics 131, 87-100.

Kubick, T. R./Lynch, D. P./Mayberry, M. A./Omer, T. C. (2015), Product Market Power and Tax Avoidance: Market Leaders, Mimicking Strategies, and Stock Returns, The Accounting Review 90 (2), 675-702.

Lamensch, M. (2018), Rendering Platforms Liable to Collect and Pay VAT on B2C Imports: A Silver Bullet?, International VAT Monitor 29 (2), 48-49.

Lamensch, M. (2017), European Commission's New Package of Proposals on E-Commerce: A Critical Assessment, International VAT Monitor 28 (2), 137-146.

Lamensch, M. (2016), The OECD International VAT/GST Guidelines: Completion of a (First) Major Step towards Global Coordination of Value-Added-Tax Systems, Intertax 44 (5), 360-373.

Lerner, A. P. (1934), The concept of monopoly and the measurement of monopoly, Review of Economic Studies 1, 157-175. 
Maffini, G./Mokkas, S. (2011), Profit Shfiting and Measured Productivity of Multinational Firms, Oxford Bulletin of Economics and Statistics 73 (1), 1-20.

Matesanz, F. (2018), Transfer Pricing Adjustments and VAT, International VAT Monitor 29 (1), 6-10.

McLure, C. E. (2002), EU and US Sales Taxes in the Digital Age: A Comparative Analysis, Bulletin for International Bureau of Fiscal Documentation 56 (4), 135-145.

OECD (2018), Tax Challenges Arising from Digitalisation - 2018 Interim Report, OECD/G20 Base Erosion and Profit Shifting Project, OECD Publishings, Paris.

OECD (2017a), Mechanisms for the Effective Collection of VAT/GST, OECD Publishing, Paris.

OECD (2017b), OECD Transfer Pricing Guidelines for Multinational Enterprises and Tax Administrations 2017, OECD Publishing, Paris.

OECD (2015), Addressing the Tax Challenges of the Digital Economy, Action 1 - 2015 Final Report, OECD/G20 Base Erosion and Profit Shifting Project, OECD Publishings, Paris.

Olbert, M./Spengel, C. (2017), International Taxation in the Digital Economy: Challenge Accepted?, World Tax Journal 9 (1), 3-46.

Petruzzi, R./Buriak, S. (2018), Addressing the Tax Challenges of the Digitalization of the Economy - A Possible Answer in the Proper Application of the Transfer Pricing Rules?, Bulletin for International Taxation 72 (4a)/Special Issue.

Pomeranz, D. (2015), No Taxation without Information: Deterrence and Self-Enforcement in the Value Added Tax, American Economic Review 105 (8), 2539-2569.

Poterba, J. M. (1996), Retail Price Reactions to Changes in State and Local Sales Taxes, National Tax Journal 49 (2), 165-176.

Robinson, L. (2012), Corporate Non-Income Tax Avoidance, Working Paper, Tuck School of Business.

Robinson, L./Slemrod, J. (2012), Understanding Multidimensional Tax Systems, International Tax and Public Finance 19, 237-267.

Rozema, K. (2018), Tax Incidence in a Vertical Supply Chain: Evidence from Cigarette Wholesale Prices, National Tax Journal 71 (3), 427-450.

Scanlan, M. (2007), Tax Sensitivity in Electronic Commerce, Fiscal Studies 28 (4), 417-436.

Scholes, M.S./Wolfson, M. A./Erickson, M./Hanlon, M./Maydew, E./Shevlin, T. (2015), Taxes \& Business Strategy, Prentice Hall, Upper Saddle River.

Scholes, M. S./Wolfson, M. A. (1992), Taxes and Business Strategy: A Planning Approach, Prentice Hall, Englewood Cliffs.

Scott, M. (2015), Digital Tax Increase to Take Effect in Europe, International New York Times (online) 1 January 2015, available at: https://www.nytimes.com/2015/01/02/business/international/digital-tax-increase-to-takeeffect-in-europe.html.

Slemrod, J. (2008), Does It Matter Who Writes the Check to the Government? The Economics of Tax Remittance, National Tax Journal 61 (2), 251-75. 
Swenson, D. (2001), Tax Reform and Evidence of Transfer Pricing, National Tax Journal 54, 7-25.

The Guardian (online) 13 October 2016, Netflix paid less than $£ 400,000$ in UK corporation tax last year, available at: https://www.theguardian.com/business/2016/oct/13/netflix-uk-corporation-tax.

The Guardian (online) 23 May 2015, Amazon to begin paying corporation tax on UK retail sales, available at: https://www.theguardian.com/technology/2015/may/23/amazon-tobegin-paying-corporation-tax-on-uk-retail-sales.

The Guardian (online) 24 October 2012, Amazon to be stripped of tax advantage on sale of ebooks, available at: https://www.theguardian.com/technology/2012/oct/24/amazon-taxloophole-ebooks.

The Wall Street Journal (online) 21 September 2017, EU Preps Tax Crackdown on Silicon Valley, available at: https://www.wsj.com/articles/eu-preps-tax-crackdown-on-siliconvalley-1505988538.

Van de Leur, M. (2017), New EU Proposals to Change Cross-Border B2B VAT Rules, International VAT Monitor 28 (6), 433-434.

Virmani, A. (1989), Indirect Tax Evasion and Production Efficiency, Journal of Publc Economics 39 (2), 223-237.

Waerzeggers, C. (2015), VAT Collection and Compliance in the Digital Economy: Challenges and Opportunities, in: Lang/Lejeune (Eds.), VAT/GST in a Global Digital Economy (2015), Alphen aan den Rijn.

Worldbank and PwC (2007-2015), Paying taxes, available at: http://www.doingbusiness.org/data/exploretopics/paying-taxes.

Yilmazkuday, H. (2017), Asymmetric Incidence of Sales Taxes: A Short-Run Investigation of Gasoline Prices, International Journal of the Economics of Business 91, 16-23. 


\section{Appendix}

Figure 1: General Collection Process of Value-added Tax in Europe

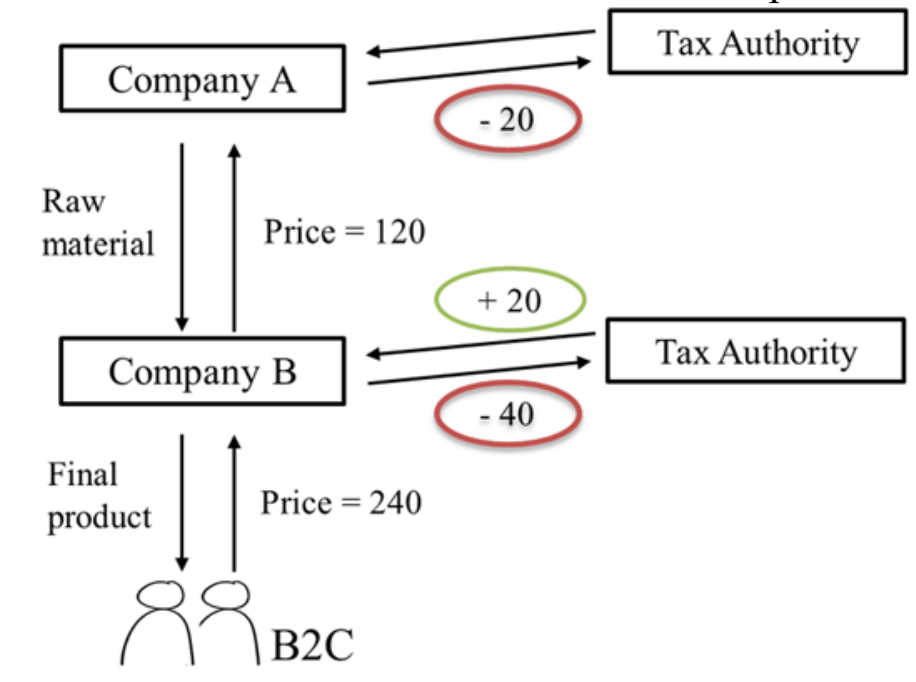

- Company A's net of VAT-profit: 100=120-20

- Company B's net of VAT-profit: $100=240-40-120+20$

- Consumer: pays 240

- Total VAT revenue: $40=20-20+40$

This figure illustrates the mechanism of the value-added tax in Europe. Company B is located in a country with an applicable VAT rate of $20 \%$. The company incurs input costs of 100 (net) plus VAT on its input of 20. Company A, the supplier, receives a gross price of 120 and remits 20 of VAT to the tax authority. Company B is granted an input VAT refund of 20. Company B adds another 100 of value and sells the final product/service to consumers at gross price of 240 . This includes VAT of $40(20 \%$ on a net price of 200), which the company remits (on behalf of the final consumer) to the tax authority. The service provide B realizes a net profit of $100(=240-40-120+20)$. 
Figure 2: Tax Incidence under VAT increase from $20 \%$ to $30 \%$

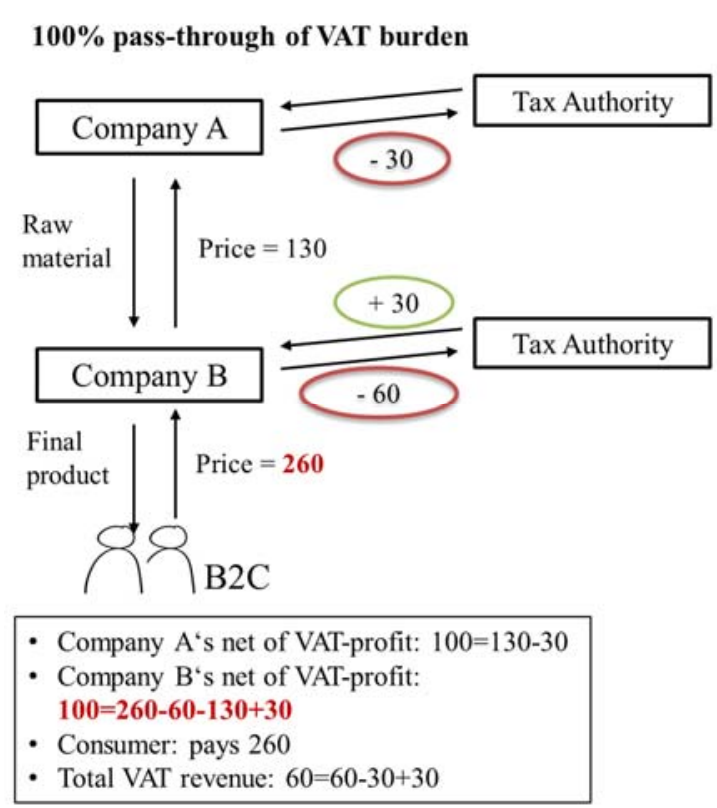

$0 \%$ pass-through of VAT burden

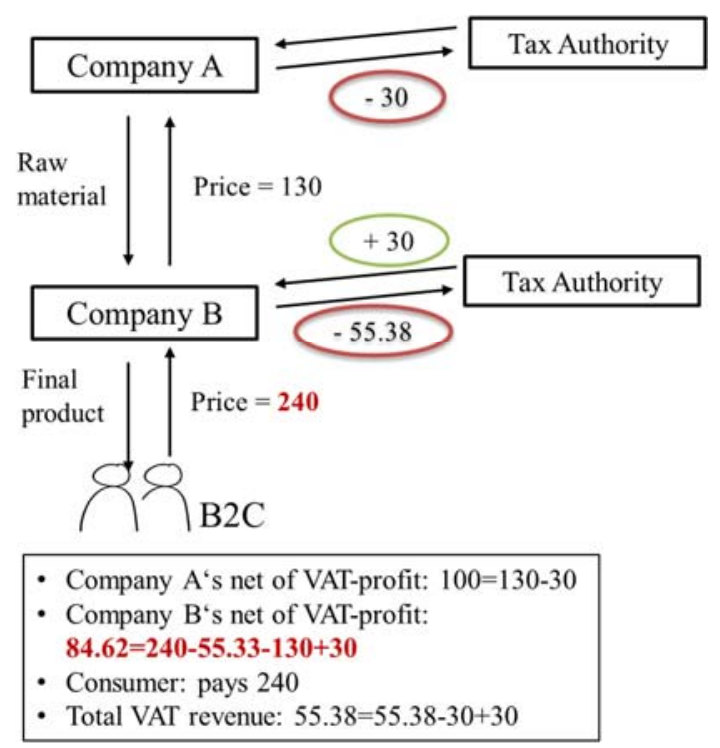

This figure illustrates the tax incidence falling partly on firms for the example of a VAT rate increase from $20 \%$ to $30 \%$. Company B used to charge a final price of 240 when the VAT was $20 \%$ (see Figure 1). It may now be able to increase the final price by the same proportional amount as the VAT rate increase and charge a final price of 260 (left-hand side of the figure). This would mean the pass-through of the VAT increase is $100 \%$ and the consumer bears the full burden of the tax increase. Company B will again realize a net-of VAT profit of 100. If the consumer is however price sensitive and not willing to pay more, company B cannot increase the final price and will remain charging 240 from the consumer (right-hand side of the figure). This would mean the pass-through of the VAT increase is $0 \%$ and the consumers bear none of the tax increase but the firm bears all of it. Company B's net-of VAT profit then looks different and is reduced to 84.62. The final price of 240 includes VAT at a rate of $30 \%$, i.e. 55.38, that company $\mathrm{B}$ has to remit to the tax authority. 
Table 1: Sample Composition (Affiliate-year Observations by Country)

\begin{tabular}{l|rr} 
Country & Total Sample & \\
\hline & Obs. & $\%$ \\
\hline BE & 8,692 & 2.74 \\
BG & 2,676 & 0.84 \\
CZ & 6,254 & 1.97 \\
DE & 6,899 & 2.18 \\
DK & 168 & 0.05 \\
EE & 3,410 & 1.08 \\
ES & 75,458 & 23.81 \\
FI & 10,514 & 3.32 \\
FR & 56,535 & 17.84 \\
GB & 21,677 & 6.84 \\
HR & 405 & 0.13 \\
HU & 297 & 0.09 \\
IE & 1,037 & 0.33 \\
IT & 61,959 & 19.55 \\
LU & 175 & 0.06 \\
LV & 79 & 0.02 \\
NL & 344 & 0.11 \\
NO & 17,813 & 5.62 \\
PL & 1,063 & 0.34 \\
PT & 14,889 & 4.70 \\
RO & 789 & 0.25 \\
SE & 16,859 & 5.32 \\
SI & 6,244 & 1.97 \\
SK & 2,664 & 0.84 \\
\hline Total & 316,900 & 100.00 \\
\hline TL &
\end{tabular}

The final sample used for our main analyses consists of 316,900 affiliate-year observations from 78,954 unique affiliates located in 24 European countries between 2007 and 2015. 
Table 2: Definition of Variables

\begin{tabular}{|c|c|}
\hline Variable & Description \\
\hline$V A T$ & Value-added tax rate applicable in the respective country (in decimals). \\
\hline$C I T$ & Corporate income tax rate in in the respective country (in decimals). \\
\hline Vatminus & $\begin{array}{l}\text { Dummy for VAT rate decrease: } 1 \text { if observed affiliate-year VAT rate is lower } \\
\text { than in the previous observed affiliate-year. }\end{array}$ \\
\hline Vatplus & $\begin{array}{l}\text { Dummy for VAT rate increase: } 1 \text { if observed affiliate-year VAT rate is higher } \\
\text { than in the previous observed affiliate-year. }\end{array}$ \\
\hline LowCIT & $\begin{array}{l}\text { Dummy equal to } 1 \text { if CIT at or below median compared to sample firms (or } \\
\text { lower than } 21 \% \text { ), } 0 \text { otherwise. }\end{array}$ \\
\hline$\triangle V A T$ & $\begin{array}{l}\text { Firm-level VAT sensitivity w.r.t. sales reporting; the measure is calculated } \\
\text { based on the respective coefficients from the regression on sales reporting }\end{array}$ \\
\hline LogSales & Natural logarithm of affiliate's sales \\
\hline LogEbit & Natural logarithm of affiliate's earnings before interest and tax (ebit) \\
\hline $\operatorname{LogPexp}$ & Natural logarithm of affiliate's personnel expenditure \\
\hline LogAssets & Natural logarithm of affiliate's total assets \\
\hline LogGroupsales & Natural logarithm of aggregate sales of all entities in same group \\
\hline RoA & Return on Assets measured as affiliate's ebit scaled by total assets \\
\hline IntExpoA & $\begin{array}{l}\text { Interest Expense over Assets, measured as affiliate's interest expense (differ- } \\
\text { ence between ebit and ebt) scaled by total assets }\end{array}$ \\
\hline Highassetshare & $\begin{array}{l}\text { Dummy equal to } 1 \text { if affiliate's share of total assets to total assets of the in- } \\
\text { dustry segment is in the highest quartile of industry total assets sorted by } \\
\text { country and year in t-1, } 0 \text { otherwise }\end{array}$ \\
\hline Digital & $\begin{array}{l}\text { Dummy equal to } 1 \text { for digital service provider affiliates: } 1 \text { if NACE Rev } 2 \\
\text { classification (NACE } 1 \text { in Amadeus) belongs to the potential group of digital } \\
\text { services, } 0 \text { otherwise (see Table 15) }\end{array}$ \\
\hline B2C_non-digital & $\begin{array}{l}\text { Dummy equal to } 1 \text { for service provider affiliates selling non-digital services } \\
\text { in the } \mathrm{B} 2 \mathrm{C} \text { segment, } 0 \text { otherwise }\end{array}$ \\
\hline Intrafirm & $\begin{array}{l}\text { Dummy equal to } 1 \text { for service provider affiliates selling services mainly intra- } \\
\text { group, i.e. when parent firm not a service provider itself nor a holding com- } \\
\text { pany (GUO is industrial firm), } 0 \text { otherwise }\end{array}$ \\
\hline$B 2 B$ & $\begin{array}{l}\text { Dummy equal to } 1 \text { for service provider affiliates active in the B2B segment, } 0 \\
\text { otherwise }\end{array}$ \\
\hline Multi & $\begin{array}{l}\text { Dummy equal to } 1 \text { if country of parent differs from country of affiliate (i.e. } \\
\text { foreign), } 0 \text { otherwise }\end{array}$ \\
\hline Intl & $\begin{array}{l}\text { Dummy equal to } 1 \text { affiliate belongs to a MNE group for which we observe af- } \\
\text { filiates in at least two countries in the sample, } 0 \text { otherwise }\end{array}$ \\
\hline Inflation & Country-specific rate of inflation (in decimals). \\
\hline LogConsPrice & $\begin{array}{l}\text { Natural logarithm of indexed consumer price levels for the total services sec- } \\
\text { tor. Country-specific price levels are indexed ( } 100 \text { being the EU- } 28 \text { average) } \\
\text { and measured in purchasing parity power. }\end{array}$ \\
\hline $\log G D P$ & Natural logarithm of country's gross domestic product per capita \\
\hline InterestLimit & $\begin{array}{l}\text { Dummy equal to } 1 \text { if country has implemented an interest deduction limita- } \\
\text { tion regulation, } 0 \text { otherwise }\end{array}$ \\
\hline Ttc_c & $\begin{array}{l}\text { Time to comply regarding consumption taxes, measured in hours, taken from } \\
\text { PwC and World Bank Group's annual report "Paying Taxes" }\end{array}$ \\
\hline
\end{tabular}

Sources: VAT rates are taken from KPMG; CIT rates are based on effective tax rates in European Commission/ZEW (2016) and KPMG. GDP data is from the Worldbank's World Development Indicators database. Consumer price levels and inflation rates data is from Eurostat. Ttc_c is from World Bank Group/PwC. InterestLimit is from the IBFD European Tax Handbooks. 
Table 3: Summary Statistics for Regressions

\begin{tabular}{lcrrrr}
\hline \multicolumn{1}{c}{ Variable } & unit & mean & \multicolumn{1}{c}{ sd } & \multicolumn{1}{c}{ min } & \multicolumn{1}{c}{ max } \\
\hline Sales & EUR ,000 & $20,923.62$ & $256,566.75$ & 500.00 & $44,436,615.00$ \\
Ebit & EUR ,000 & $1,854.87$ & $31,544.38$ & 1.00 & $4,356,366.00$ \\
VAT & - & 0.21 & 0.02 & 0.15 & 0.27 \\
CIT & - & 0.31 & 0.06 & 0.10 & 0.39 \\
AVAT & - & -0.37 & 3.47 & -14.09 & 12.69 \\
Pexp & EUR, 000 & $4,363.12$ & $42,072.40$ & 1.00 & $6,707,383.00$ \\
Assets & EUR ,000 & $28,985.98$ & $427,909.67$ & 9.00 & $79,242,530.00$ \\
GDP & EUR/capita & $39,162.54$ & $16,228.24$ & $5,932.90$ & $119,172.74$ \\
ConsPrice & Normalized (100) & 105.22 & 24.84 & 27.70 & 187.00 \\
Inflation & - & 0.02 & 0.01 & -0.02 & 0.15 \\
Ttc_c & Hours & 57.53 & 55.17 & 16.00 & 360.00 \\
\hline
\end{tabular}

The sample used in the main empirical tests consists of 316,900 affiliate-year observations from 78,954 unique affiliates of 63,958 global ultimate owners located in 24 European countries between 2007 and 2015. This table reports summary statistics for the constructed variable $\triangle V A T$, which measures the firmspecific VAT sensitivity w.r.t. reporting sales. The measure is derived by running a regression based on equation (1) (excluding the interaction of VAT and foreign-owned firms) with VAT interacted with the firm fixed effects vector. The point estimate for this interaction term is then multiplied by -1 and labelled $\triangle V A T$.

Table 4: Correlation Matrix

\begin{tabular}{|c|c|c|c|c|c|c|c|c|c|c|c|}
\hline Variables & (1) & (2) & (3) & (4) & (5) & (6) & (7) & (8) & (9) & (10) & (11) \\
\hline (1) Sales & 1.00 & & & & & & & & & & \\
\hline (2) $E B I T$ & 0.511 & 1.00 & & & & & & & & & \\
\hline (3) $V A T$ & -0.031 & -0.025 & 1.00 & & & & & & & & \\
\hline (4) $C I T$ & -0.011 & -0.008 & -0.420 & 1.00 & & & & & & & \\
\hline (5) $Р \exp$ & 0.473 & 0.378 & -0.037 & -0.007 & 1.00 & & & & & & \\
\hline (6) Assets & 0.497 & 0.544 & -0.021 & -0.015 & 0.466 & 1.00 & & & & & \\
\hline (7) $G D P$ & 0.007 & 0.002 & 0.456 & -0.053 & 0.010 & 0.003 & 1.00 & & & & \\
\hline (8) ConsPrice & 0.019 & 0.012 & 0.354 & 0.054 & 0.027 & 0.013 & 0.917 & 1.00 & & & \\
\hline (9) Inflation & 0.010 & 0.008 & -0.203 & -0.071 & 0.011 & 0.005 & 0.063 & -0.006 & 1.00 & & \\
\hline (10) $\triangle V A T$ & -0.032 & -0.017 & 0.047 & -0.031 & -0.021 & -0.014 & 0.043 & 0.036 & -0.003 & 1.00 & \\
\hline (11) $T t c \_c$ & -0.015 & -0.004 & -0.359 & -0.034 & -0.021 & -0.010 & -0.276 & -0.415 & 0.203 & 0.019 & 1.00 \\
\hline
\end{tabular}

This table presents the correlations between our main control variables and variables of interest. 
Table 5: Sales Reporting and Consumption Taxes

\begin{tabular}{|c|c|c|c|c|c|}
\hline $\begin{array}{l}\text { Dep. Var.: } \\
\text { LogSales }\end{array}$ & $\begin{array}{c}\text { (1) } \\
\text { Prod. Fctn. }\end{array}$ & $\begin{array}{c}(2) \\
\text { VAT }\end{array}$ & $\begin{array}{l}(3) \\
\text { VAT } \\
\text { CIT } \\
\end{array}$ & $\begin{array}{c}\text { (4) } \\
\text { Foreign } \\
\text { Parent }\end{array}$ & $\begin{array}{c}(5) \\
\text { Digital }\end{array}$ \\
\hline$\overline{V A T}$ & & $\begin{array}{c}-0.4341 * * * \\
(0.0820)\end{array}$ & $\begin{array}{c}-0.5201 * * * \\
(0.0835)\end{array}$ & $\begin{array}{c}-0.7592 * * * \\
(0.0950)\end{array}$ & $\begin{array}{c}-0.4318 * * * \\
(0.0850)\end{array}$ \\
\hline Multi*VAT & & & & $\begin{array}{c}0.5582 * * * \\
(0.1340)\end{array}$ & \\
\hline Digital $^{*} V A T$ & & & & & $\begin{array}{c}-1.2304 * * * \\
(0.2298)\end{array}$ \\
\hline CIT & & & $\begin{array}{c}-0.1451 * * * \\
(0.0413)\end{array}$ & $\begin{array}{l}-0.0505 \\
(0.0514)\end{array}$ & $\begin{array}{c}-0.1469 * * * \\
(0.0418)\end{array}$ \\
\hline Multi ${ }^{*} C I T$ & & & & $\begin{array}{c}-0.2591 * * * \\
(0.0786)\end{array}$ & \\
\hline Digital $^{*} C I T$ & & & & & $\begin{array}{c}0.0517 \\
(0.1825)\end{array}$ \\
\hline$T t c \_c$ & & $\begin{array}{c}0.0002 * * * \\
(0.0000)\end{array}$ & $\begin{array}{c}0.0002 * * * \\
(0.0000)\end{array}$ & $\begin{array}{c}0.0002 * * * \\
(0.0000)\end{array}$ & $\begin{array}{c}0.0002 * * * \\
(0.0000)\end{array}$ \\
\hline LogPexp & $\begin{array}{c}0.3497 * * * \\
(0.0054)\end{array}$ & $\begin{array}{c}0.3488^{* * * *} \\
(0.0054)\end{array}$ & $\begin{array}{c}0.3487 * * * \\
(0.0054)\end{array}$ & $\begin{array}{c}0.3485 * * * \\
(0.0054)\end{array}$ & $\begin{array}{c}0.3487 * * * \\
(0.0054)\end{array}$ \\
\hline LogAssets & $\begin{array}{c}0.4189 * * * \\
(0.0044)\end{array}$ & $\begin{array}{c}0.4184 * * * \\
(0.0044)\end{array}$ & $\begin{array}{c}0.4183 * * * \\
(0.0044)\end{array}$ & $\begin{array}{c}0.4181 * * * \\
(0.0044)\end{array}$ & $\begin{array}{c}0.4187 * * * \\
(0.0044)\end{array}$ \\
\hline $\log G D P$ & $\begin{array}{c}0.5865 * * * \\
(0.0213)\end{array}$ & $\begin{array}{c}0.4389 * * * \\
(0.0235)\end{array}$ & $\begin{array}{c}0.4420 * * * \\
(0.0235)\end{array}$ & $\begin{array}{c}0.4224 * * * \\
(0.0236)\end{array}$ & $\begin{array}{c}0.4411 * * * \\
(0.0235)\end{array}$ \\
\hline LogConsPrice & $\begin{array}{c}-0.2290 * * * \\
(0.0225)\end{array}$ & $\begin{array}{c}-0.1468 * * * \\
(0.0235)\end{array}$ & $\begin{array}{c}-0.1694 * * * \\
(0.0237)\end{array}$ & $\begin{array}{c}-0.1606 * * * \\
(0.0237)\end{array}$ & $\begin{array}{c}-0.1689 * * * \\
(0.0237)\end{array}$ \\
\hline Inflation & $\begin{array}{c}1.5632 * * * \\
(0.0844)\end{array}$ & $\begin{array}{c}1.1138^{* * * *} \\
(0.0854)\end{array}$ & $\begin{array}{c}1.1208 * * * \\
(0.0854)\end{array}$ & $\begin{array}{c}1.1031 * * * \\
(0.0856)\end{array}$ & $\begin{array}{c}1.1204 * * * \\
(0.0854)\end{array}$ \\
\hline Constant & $\begin{array}{c}-2.5844 * * * \\
(0.1621)\end{array}$ & $\begin{array}{c}-1.3276 * * * \\
(0.1837)\end{array}$ & $\begin{array}{c}-1.1906^{* * * *} \\
(0.1853)\end{array}$ & $\begin{array}{c}-1.0123 * * * \\
(0.1871)\end{array}$ & $\begin{array}{c}-1.1899 * * * \\
(0.1851)\end{array}$ \\
\hline Observations & 316,900 & 316,900 & 316,900 & 316,900 & 316,900 \\
\hline R-squared & 0.5368 & 0.5374 & 0.5374 & 0.5376 & 0.5376 \\
\hline Firm FE & YES & YES & YES & YES & YES \\
\hline Year FE & YES & YES & YES & YES & YES \\
\hline
\end{tabular}

This table reports coefficient estimates from linear panel regressions on the affiliate level, using a fixed effects model and robust standard errors. The sample consists of 316,900 affiliate-year observations from affiliates located in 24 European countries between 2007 and 2015 with sufficient data from Amadeus for the regressions. The dependent variable is the natural logarithm of the affiliate's operating revenue (sales). Column (1) reports results for a parsimonious model of the typical productivity estimation using the full sample. Column (2) includes the VAT rate as the variable of interest to examine the sales reporting behaviour of service affiliates. Column (3) also includes the CIT rate to control for other features of the tax system. Column (4) includes the indicator variable Multi for foreign global ultimate owners and the interaction with the VAT rate. Column (5) includes the indicator variable Digital and the interaction with the VAT rate. Tests of joint significance yield a p-value smaller than 0.01 for each case of interactions. Robust standard errors, clustered on affiliate level, are presented in parentheses. *, ** and *** represent two-tailed statistical significance at the $10 \%, 5 \%$ and $1 \%$ levels, respectively. 
Table 6: Cross-sectional Tests: Industries

\begin{tabular}{|c|c|c|c|c|c|}
\hline Dep. Var.: & (1) & (2) & (3) & (4) & (5) \\
\hline LogSales & Baseline & Digital & $\begin{array}{c}\mathrm{B} 2 \mathrm{C} \\
\text { non-digital }\end{array}$ & Intrafirm & $\mathrm{B} 2 \mathrm{~B}$ \\
\hline$V A T$ & $\begin{array}{c}-0.5201 * * * \\
(0.0835)\end{array}$ & & & & \\
\hline Industry*VAT & & $\begin{array}{c}-1.2417 * * * \\
(0.2318)\end{array}$ & $\begin{array}{c}-0.9286^{* * *} \\
(0.1230)\end{array}$ & $\begin{array}{c}1.0806 * * * \\
(0.3454)\end{array}$ & $\begin{array}{c}0.8445 * * * \\
(0.1235)\end{array}$ \\
\hline Observations & 316,900 & 299,900 & 299,900 & 119,984 & 299,900 \\
\hline R-squared & 0.5374 & 0.9842 & 0.9842 & 0.9853 & 0.9842 \\
\hline Firm controls & YES & YES & YES & YES & YES \\
\hline Firm FE & YES & YES & YES & YES & YES \\
\hline Year FE & YES & $\mathrm{NO}$ & $\mathrm{NO}$ & $\mathrm{NO}$ & $\mathrm{NO}$ \\
\hline Country-Year FE & $\mathrm{NO}$ & YES & YES & YES & YES \\
\hline
\end{tabular}

This table reports coefficient estimates from linear panel regressions on the affiliate level, using a fixed effects model and robust standard errors. The dependent variable is the natural logarithm of the affiliate's operating revenue (sales). Column (1) reports results of our main specification (Table 5 column (3)). The constant term is not reported here. Columns (2) to (5) include the VAT rate interacted with an indicator variable for the respective industry segments Industry*VAT (where Industry is Digital, B2C_non-digital, Intrafirm, respectively $B 2 B$ ). Robust standard errors, clustered on affiliate level, are presented in parentheses. ${ }^{*}, *$ and $* * *$ represent two-tailed statistical significance at the $10 \%, 5 \%$ and $1 \%$ levels, respectively. 
Table 7: Cross-sectional Tests: Industries and Market Share (Total Assets) in t-1

\begin{tabular}{|c|c|c|c|c|c|}
\hline $\begin{array}{l}\text { Dep. Var.: } \\
\text { LogSales }\end{array}$ & $\begin{array}{c}(1) \\
\text { Baseline }\end{array}$ & $\begin{array}{c}(2) \\
\text { Digital }\end{array}$ & $\begin{array}{c}\text { (3) } \\
\text { B2C } \\
\text { non-digital }\end{array}$ & $\begin{array}{c}\text { (4) } \\
\text { Intrafirm }\end{array}$ & $\begin{array}{c}(5) \\
B 2 B\end{array}$ \\
\hline$V A T$ & $\begin{array}{c}-0.8879 * * * \\
(0.1005)\end{array}$ & & & & \\
\hline Highassetshare & $\begin{array}{c}-0.1271 * * * \\
(0.0300)\end{array}$ & $\begin{array}{c}-0.0966^{* * *} \\
(0.0315)\end{array}$ & $\begin{array}{l}-0.0560^{*} \\
(0.0323)\end{array}$ & $\begin{array}{l}-0.0893 * \\
(0.0483)\end{array}$ & $\begin{array}{c}-0.1159 * * * \\
(0.0317)\end{array}$ \\
\hline Industry*VAT & & $\begin{array}{c}-0.9042 * * * \\
(0.2694)\end{array}$ & $\begin{array}{c}-0.7511 * * * \\
(0.1335)\end{array}$ & $\begin{array}{l}0.8813^{* *} \\
(0.3517)\end{array}$ & $\begin{array}{c}0.7721 * * * \\
(0.1367)\end{array}$ \\
\hline Highassetshare ${ }^{*} V A T$ & $\begin{array}{l}0.7101 * * * \\
(0.1488)\end{array}$ & $\begin{array}{c}0.5597 * * * \\
(0.1569)\end{array}$ & $\begin{array}{c}0.3774 * * \\
(0.1597)\end{array}$ & $\begin{array}{l}0.4564^{*} \\
(0.2411)\end{array}$ & $\begin{array}{c}0.5812 * * * \\
(0.1585)\end{array}$ \\
\hline $\begin{array}{l}\text { Industry* } \\
\text { Highassetshare*VAT }\end{array}$ & & $\begin{array}{c}-0.3272 * * * \\
(0.0640)\end{array}$ & $\begin{array}{c}-0.1521 * * * \\
(0.0342)\end{array}$ & $\begin{array}{l}-0.1089 \\
(0.0745)\end{array}$ & $\begin{array}{c}0.1445 * * * \\
(0.0317)\end{array}$ \\
\hline Observations & 223,779 & 210,296 & 210,296 & 84,522 & 210,296 \\
\hline R-squared & 0.5093 & 0.9878 & 0.9878 & 0.9888 & 0.9878 \\
\hline Firm controls & YES & YES & YES & YES & YES \\
\hline Firm FE & YES & YES & YES & YES & YES \\
\hline Year FE & YES & $\mathrm{NO}$ & $\mathrm{NO}$ & $\mathrm{NO}$ & $\mathrm{NO}$ \\
\hline Country-Year FE & $\mathrm{NO}$ & YES & YES & YES & YES \\
\hline
\end{tabular}

This table reports coefficient estimates from linear panel regressions on the affiliate level, using a fixed effects model and robust standard errors. The dependent variable is the natural logarithm of the affiliate's operating revenue (sales). Column (1) reports results of estimating equation (1) augmented by an interaction term of Highassetshare ${ }^{*} V A T$. The constant term is not reported here. Columns (2) to (5) include the interaction term of Highassetshare*VAT, the VAT rate interacted with an indicator variable for the respective industry segments Industry*VAT and the triple interaction term for Industry*Highassetshare*VAT. Robust standard errors, clustered on affiliate level, are presented in parentheses. ${ }^{*}, * *$ and $* * *$ represent two-tailed statistical significance at the $10 \%, 5 \%$ and $1 \%$ levels, respectively. 
Table 8: Group-level Analysis: Total Sales and Consumption Taxes

\begin{tabular}{|c|c|c|c|c|c|c|}
\hline $\begin{array}{l}\text { Dep. Var.: } \\
\text { LogGroupsales }\end{array}$ & $\begin{array}{c}(1) \\
\text { Baseline }\end{array}$ & $\begin{array}{l}(2) \\
\text { Intl }\end{array}$ & $\begin{array}{c}(3) \\
\text { Digital }\end{array}$ & $\begin{array}{c}(4) \\
\text { B2C } \\
\text { non-digita }\end{array}$ & $\begin{array}{c}5) \\
\text { Intrafirm }\end{array}$ & $\begin{array}{c}(6) \\
\text { B2B }\end{array}$ \\
\hline$V A T$ & $\begin{array}{c}-2.4552 * * * \\
(0.2227)\end{array}$ & & & & & \\
\hline $\operatorname{Intl}^{*} V A T$ & $\begin{array}{c}3.5482 * * * \\
(0.3270)\end{array}$ & $\begin{array}{c}3.4382 * * * \\
(0.3417)\end{array}$ & $\begin{array}{c}3.3073 * * * \\
(0.3613)\end{array}$ & $\begin{array}{c}3.3628 * * * \\
(0.4079)\end{array}$ & $\begin{array}{c}3.3240 * * * \\
(0.4635)\end{array}$ & $\begin{array}{c}3.5309 * * * \\
(0.3643)\end{array}$ \\
\hline Industry*VAT & & & $\begin{array}{c}-4.5920 * * * \\
(0.6069)\end{array}$ & $\begin{array}{c}0.1605 \\
(0.3927)\end{array}$ & $\begin{array}{l}-0.1358 \\
(0.6919)\end{array}$ & $\begin{array}{c}0.7668^{*} \\
(0.4309)\end{array}$ \\
\hline Industry* & & & $2.0463 * *$ & 0.2398 & 0.2356 & -0.3089 \\
\hline $\operatorname{Intl}{ }^{*} V A T$ & & & $(0.8943)$ & $(0.6918)$ & $(1.0075)$ & $(0.8189)$ \\
\hline Constant & $\begin{array}{c}6.2155^{* * *} * \\
(0.4127)\end{array}$ & & & & & \\
\hline Observations & 91,582 & 85,284 & 85,284 & 85,284 & 57,176 & 85,284 \\
\hline R-squared & 0.3025 & 0.9919 & 0.9919 & 0.9919 & 0.9924 & 0.9919 \\
\hline Firm controls & YES & YES & YES & YES & YES & YES \\
\hline Firm FE & YES & YES & YES & YES & YES & YES \\
\hline Year FE & YES & $\mathrm{NO}$ & NO & NO & NO & NO \\
\hline Country-Year FE & NO & YES & YES & YES & YES & YES \\
\hline
\end{tabular}

This table reports coefficient estimates from linear panel regressions on the affiliate level, using a fixed effects model and robust standard errors. The sample consists of all affiliate-year observations aggregated at the individual group-level (same global ultimate owner). The dependent variable is the natural logarithm of group-wide sales. Column (1) reports results of estimating equation (1) with LogGroupsales as the dependent variable and augmented by an interaction term of $I n t l^{*} V A T$. Column (2) reports results of the similar regression using country-year fixed effects. Columns (3) to (6) include the interaction term of $\operatorname{Intl}^{*} V A T$, the VAT rate interacted with an indicator variable for the respective industry segments Industry*VAT and the triple interaction term for Industry*Intl ${ }^{*} V A T$. Robust standard errors, clustered on affiliate level, are presented in parentheses. ${ }^{*}, * *$ and $* * *$ represent two-tailed statistical significance at the $10 \%, 5 \%$ and $1 \%$ levels, respectively. 
Table 9: Consumption Tax Planning and Profit Shifting Incentives

\begin{tabular}{lcc}
\hline Dep. Var.: & $(1)$ & $(2)$ \\
LogSales & CIT Median & CIT $<21 \%$ \\
\hline VATminus & $0.0299^{* * *}$ & $0.0271^{* * *}$ \\
& $(0.0047)$ & $(0.0047)$ \\
VATplus & $-0.0110^{* * *}$ & $-0.0053 * * *$ \\
& $(0.0016)$ & $(0.0011)$ \\
VATplus ${ }^{*}$ LowCIT & $0.0126 * * *$ & $0.0159 * * *$ \\
& $(0.0022)$ & $(0.0045)$ \\
VATminus ${ }^{*}$ LowCIT & & 0.0048 \\
& & $(0.0202)$ \\
Constant & $-2.0742^{* * *}$ & $-2.0092^{* * *}$ \\
& $(0.1800)$ & $(0.1808)$ \\
\hline Observations & 263,365 & 263,365 \\
R-squared & 0.5141 & 0.5141 \\
Firm Controls & YES & YES \\
Firm FE & YES & YES \\
Year FE & YES & YES \\
Country-Year FE & NO & NO \\
\hline
\end{tabular}

This table reports coefficient estimates from linear panel regressions modifying equation (1) of Table 7 by using dummy variables for VAT rate increases and decreases and including the interaction term of these dummies with an indicator variable for the CIT rate. The dependent variable is the natural logarithm of the affiliate's sales. In Column (1), the indicator is equal to one if the CIT rate in the respective country is below median of the sample.$^{59}$ In Column (2) the indicator is equal to one if the CIT rate in the respective country is below $21 \%$. Tests of joint significance yield a p-value smaller than 0.01 for each case of interactions. Robust standard errors, clustered on affiliate level, are presented in parentheses. $*, * *$ and $* * *$ represent two-tailed statistical significance at the $10 \%, 5 \%$ and $1 \%$ levels, respectively.

\footnotetext{
${ }^{59}$ The coefficient on the interaction of VATminus and LowCIT cannot be reported in column (1) since VAT rate decreases are rare (only about 2,800 observations) and hardly occur for countries in our sample with a CIT rate below median.
} 
Table 10: Profit Shifting and Consumption Taxes

\begin{tabular}{|c|c|c|c|c|}
\hline $\begin{array}{l}\text { Dep. Var.: } \\
\text { LogEbit }\end{array}$ & $\begin{array}{c}(1) \\
\text { Baseline }\end{array}$ & $\begin{array}{c}(2) \\
\text { VAT }\end{array}$ & $\begin{array}{c}\text { (3) } \\
\text { D-VAT }\end{array}$ & $\begin{array}{c}\text { (4) } \\
\text { D-VAT } \\
\text { Full Int. }\end{array}$ \\
\hline$C I T$ & $\begin{array}{c}-0.4737 * * * \\
(0.1285)\end{array}$ & $\begin{array}{c}-0.6028 * * * \\
(0.1334)\end{array}$ & $\begin{array}{c}-0.3634 * * * \\
(0.1297)\end{array}$ & $\begin{array}{c}-0.4937 * * * \\
(0.1346)\end{array}$ \\
\hline$\triangle V A T^{*} C I T$ & & & $\begin{array}{c}0.1785 * * * \\
(0.0347)\end{array}$ & $\begin{array}{c}0.1790 * * * \\
(0.0347)\end{array}$ \\
\hline$V A T$ & & $\begin{array}{c}-0.7232 * * * \\
(0.2620)\end{array}$ & & $\begin{array}{c}-0.7320 * * * \\
(0.2623)\end{array}$ \\
\hline$\triangle V A T^{*} V A T$ & & & & $\begin{array}{c}4.2952 * * * \\
(0.0950)\end{array}$ \\
\hline $\log P \exp$ & $\begin{array}{c}0.1108 * * * \\
(0.0067)\end{array}$ & $\begin{array}{c}0.1102 * * * \\
(0.0067)\end{array}$ & $\begin{array}{c}0.1094 * * * \\
(0.0068)\end{array}$ & $\begin{array}{c}0.1013 * * * \\
(0.0065)\end{array}$ \\
\hline LogAssets & $\begin{array}{c}0.7517 * * * \\
(0.0088)\end{array}$ & $\begin{array}{c}0.7517 * * * \\
(0.0088)\end{array}$ & $\begin{array}{c}0.7508 * * * \\
(0.0088)\end{array}$ & $\begin{array}{c}0.7269 * * * \\
(0.0085)\end{array}$ \\
\hline $\log G D P$ & $\begin{array}{c}0.3296 * * * \\
(0.0413)\end{array}$ & $\begin{array}{c}0.2606 * * * \\
(0.0449)\end{array}$ & $\begin{array}{c}0.3365 * * * \\
(0.0413)\end{array}$ & $\begin{array}{c}0.2849 * * * \\
(0.0444)\end{array}$ \\
\hline Constant & $\begin{array}{c}-4.6891 * * * \\
(0.4379)\end{array}$ & $\begin{array}{c}-3.7764 * * * \\
(0.5057)\end{array}$ & $\begin{array}{c}-4.7603 * * * \\
(0.4383)\end{array}$ & $\begin{array}{c}-3.6346^{* * *} \\
(0.4995)\end{array}$ \\
\hline Observations & 316,900 & 316,900 & 299,901 & 299,901 \\
\hline R-squared & 0.0958 & 0.0959 & 0.0960 & 0.1118 \\
\hline Firm FE & YES & YES & YES & YES \\
\hline Year FE & YES & YES & YES & YES \\
\hline
\end{tabular}

This table reports coefficient estimates from linear panel regressions on the affiliate level, using a fixed effects model and robust standard errors. The sample consists of 316,900 affiliate-year observations from affiliates located in 24 European countries between 2007 and 2015 with sufficient data from Amadeus for the regressions (299,901 observations when the $\triangle V A T$ measure is included respectively). The dependent variable is the natural logarithm of the affiliate's EBIT. Column (1) reports results for the benchmark profit shifting regression including the CIT rate as the variable of interest. Column (2) extends the baseline regression by including the VAT rate. Column (3) extends the baseline regression by including interaction of $\triangle V A T$, the constructed measure of firm-specific VAT sensitivity w.r.t reporting sales, and the CIT. Column (4) presents regression results of this extended model when $\triangle V A T$ is also interacted with the VAT rate. Tests of joint significance yield a p-value smaller than 0.01 for each case of interactions. Robust standard errors, clustered on MNE-group level, are presented in parentheses. ${ }^{*}, * *$ and $* * *$ represent two-tailed statistical significance at the $10 \%, 5 \%$ and $1 \%$ levels, respectively. 
Figure 3: Profit Shifting and Consumption Taxes - Marginal Effects ( $\triangle V A T)$

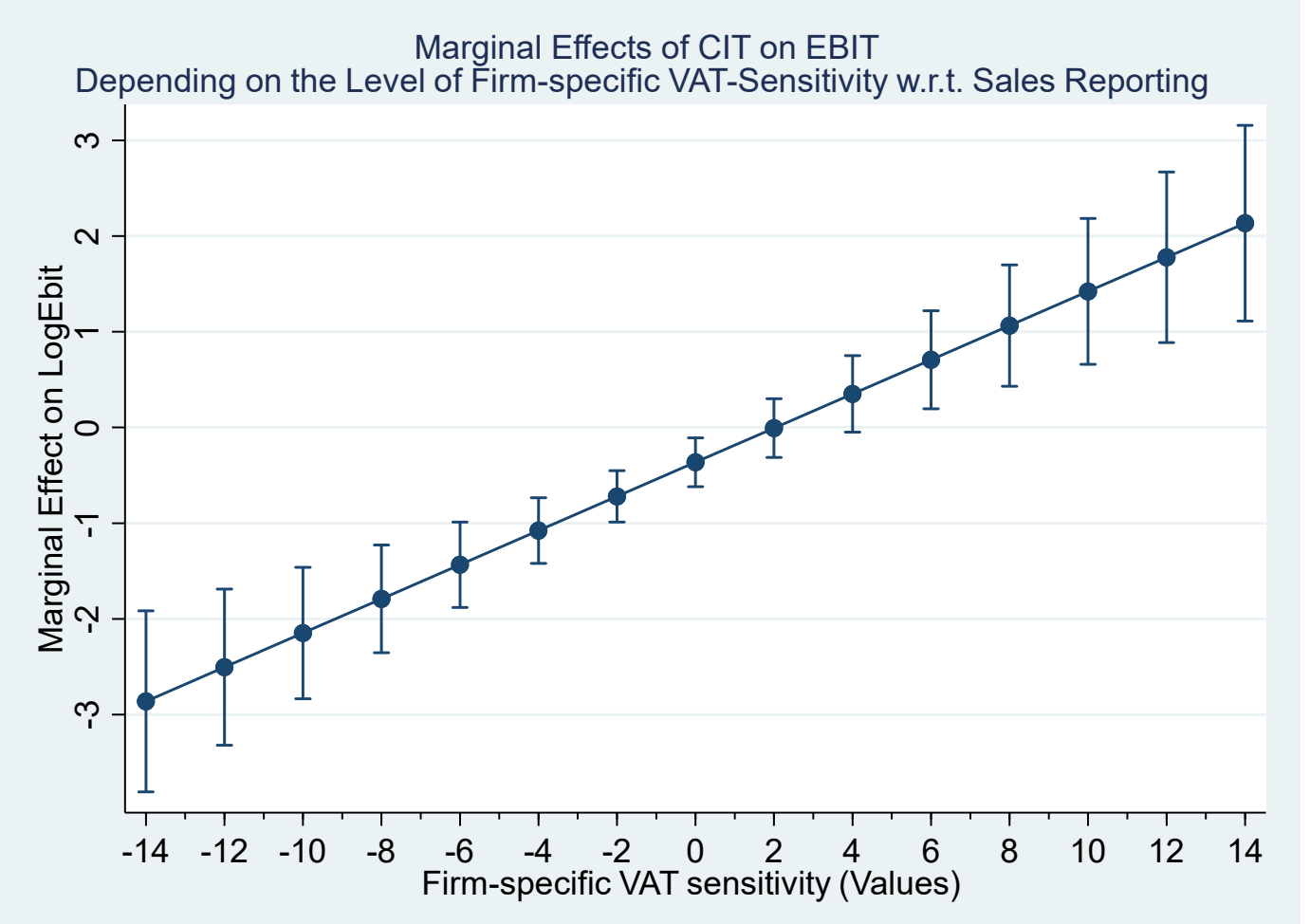

This figure illustrates the marginal effects of a change in CIT rates on reported pre-tax profits (EBIT), i.e. the measure of profit shifting, at the different values of firm-specific VAT sensitivity w.r.t. reporting sales $(\triangle V A T)$. Marginal effects are based on the regression output as depicted in Column (3) of the preceding table. 
Table 11: Profit Shifting and Consumption Taxes: Cross-Sectional Tests (Industries)

\begin{tabular}{|c|c|c|c|c|c|}
\hline $\begin{array}{l}\text { Dep. Var.: } \\
\text { LogEbit }\end{array}$ & $\begin{array}{c}(1) \\
\text { Baseline }\end{array}$ & $\begin{array}{c}(2) \\
\text { Digital }\end{array}$ & $\begin{array}{c}(3) \\
\text { B2C } \\
\text { non-digital }\end{array}$ & $\begin{array}{c}(4) \\
\text { Intrafirm }\end{array}$ & $\begin{array}{c}(5) \\
B 2 B\end{array}$ \\
\hline$C I T$ & $\begin{array}{c}-0.3634 * * * \\
(0.1297)\end{array}$ & & & & \\
\hline Industry ${ }^{*} C I T$ & & $\begin{array}{c}0.1973 \\
(0.4984)\end{array}$ & $\begin{array}{c}-0.1769 \\
(0.2384)\end{array}$ & $\begin{array}{c}0.2481 \\
(0.5909)\end{array}$ & $\begin{array}{c}0.4954 * * \\
(0.2438)\end{array}$ \\
\hline$\triangle V A T^{*} C I T$ & $\begin{array}{c}0.1785 * * * \\
(0.0347)\end{array}$ & $\begin{array}{c}0.1586^{* * *} * \\
(0.0360)\end{array}$ & $\begin{array}{c}0.0698 \\
(0.0454)\end{array}$ & $\begin{array}{c}0.2762 * * * \\
(0.0592)\end{array}$ & $\begin{array}{c}0.2627 * * * \\
(0.0419)\end{array}$ \\
\hline $\begin{array}{l}\text { Industry* } \\
\Delta V A T^{*} C I T\end{array}$ & & $\begin{array}{l}0.2661 * \\
(0.1483)\end{array}$ & $\begin{array}{c}0.2398 * * * \\
(0.0702)\end{array}$ & $\begin{array}{c}-0.0615 \\
(0.1828)\end{array}$ & $\begin{array}{c}-0.2949 * * * \\
(0.0747)\end{array}$ \\
\hline Observations & 299,901 & 299,900 & 299,900 & 119,984 & 299,900 \\
\hline R-squared & 0.0960 & 0.8550 & 0.8550 & 0.8635 & 0.8550 \\
\hline Firm Controls & YES & YES & YES & YES & YES \\
\hline Firm FE & YES & YES & YES & YES & YES \\
\hline Year FE & YES & $\mathrm{NO}$ & $\mathrm{NO}$ & $\mathrm{NO}$ & $\mathrm{NO}$ \\
\hline Country-Year FE & $\mathrm{NO}$ & YES & YES & YES & YES \\
\hline
\end{tabular}

This table reports coefficient estimates from linear panel regressions on the affiliate level, using a fixed effects model and robust standard errors. The sample consists of 299,901 affiliate-year observations since we include the $\triangle V A T$ measure. The dependent variable is the natural logarithm of the affiliate's EBIT. Column (1) reports results of estimating equation (2) including the interaction of the CIT rate and the $\triangle V A T$ measure. The constant term is not reported here. Columns (2) to (5) include the interaction term of $\triangle V A T^{*} C I T$, the CIT rate interacted with an indicator variable for the respective industry segments Industry*VAT and the triple interaction term for Industry* $\triangle V A T^{*} V A T$. Tests of joint significance yield a p-value smaller than 0.01 for each case of interactions. Robust standard errors, clustered on MNE-group level, are presented in parentheses. ${ }^{*}, * *$ and $* * *$ and represent two-tailed statistical significance at the $10 \%, 5 \%$ and $1 \%$ levels, respectively. 
Table 12: Profit Shifting Channels and Consumption Taxes

\begin{tabular}{lccccc}
\hline & $(1)$ & $(2)$ & $(3)$ & $(4)$ & $(5)$ \\
Dep. Var.: & RoA & IntExpoA & RoA & IntExpoA & IntExpoA \\
\hline$C I T$ & $-0.0526^{* * *}$ & $0.0047^{*}$ & & & \\
& $(0.0106)$ & $(0.0026)$ & & & \\
$\Delta V A T^{*} C I T$ & $0.0176^{* * *}$ & $0.0019^{* * *}$ & $0.0158^{* * *}$ & $0.0021^{* * *}$ & $0.0023^{* * *}$ \\
& $(0.0028)$ & $(0.0007)$ & $(0.0029)$ & $(0.0007)$ & $(0.0007)$ \\
InterestLimit $*$ & & & & -0.0000 \\
$\Delta V A T^{*} C I T$ & & & & $(0.0001)$ \\
LogPexp & $0.0052^{* * *}$ & $0.0011^{* * *}$ & $0.0055^{* * *}$ & $0.0013^{* * *}$ & $0.0013^{* * *}$ \\
& $(0.0006)$ & $(0.0001)$ & $(0.0006)$ & $(0.0001)$ & $(0.0001)$ \\
LogAssets & $-0.0243^{* * *}$ & $-0.0030^{* * *}$ & $-0.0248^{* * *}$ & $-0.0030^{* * *}$ & $-0.0030^{* * *}$ \\
& $(0.0009)$ & $(0.0002)$ & $(0.0009)$ & $(0.0002)$ & $(0.0002)$ \\
LogGDP & $0.0165^{* * *}$ & $-0.0045^{* * *}$ & & & \\
& $(0.0038)$ & $(0.0009)$ & & & \\
Constant & $0.1141^{* * *}$ & $0.0753^{* * *}$ & & & \\
& $(0.0396)$ & $(0.0095)$ & & & \\
\hline Observations & 299,901 & 299,901 & 299,900 & 299,900 & 299,900 \\
R-squared & 0.0269 & 0.0141 & 0.6804 & 0.6240 & 0.6240 \\
Firm FE & YES & YES & YES & YES & YES \\
Year FE & YES & YES & NO & NO & NO \\
Country-Year FE & NO & NO & YES & YES & YES \\
\hline
\end{tabular}

This table reports coefficient estimates from linear panel regressions on the affiliate level, using a fixed effects model and robust standard errors. The sample consists of 299,901 affiliate-year observations since we include the $\triangle V A T$ measure. The dependent variable is the affiliate's Return on Assets $(R o A)$ in columns (1) and (3) and the affiliate's ratio of interest expense to total assets (IntExpoA) in columns (2), (4) and (5). Column (1) reports results of estimating equation (2) with $R o A$ as the dependent variable including the interaction of the CIT rate and the $\triangle V A T$ measure. Column (2) reports results of estimating equation (2) with IntExpoA as the dependent variable including the interaction of the CIT rate and the $\triangle V A T$ measure. Columns (3) and (4) repeat these tests including country-year fixed effects. Column (5) extends the specification from column (4) by additionally interacting the $\triangle V A T^{*} C I T$ interaction with an indicator variable for the existence of interest deductibility limitation rules. Tests of joint significance yield a p-value smaller than 0.01 for each case of interactions. Robust standard errors, clustered on MNE-group level, are presented in parentheses. *, ** and *** and represent two-tailed statistical significance at the $10 \%, 5 \%$ and $1 \%$ levels, respectively. 


\section{Online Appendix}

Table 13: VAT and CIT Rate Changes 2007-2015

Panel A: VAT Rates and Changes for Sample Countries

\begin{tabular}{|c|c|c|c|c|c|c|c|c|c|c|}
\hline & 2007 & $\Delta 2008$ & $\Delta 2009$ & $\Delta 2010$ & $\Delta 2011$ & $\Delta 2012$ & $\Delta 2013$ & $\Delta 2014$ & $\Delta 2015$ & 2015 \\
\hline $\mathrm{BE}$ & 21.00 & - & - & - & - & - & - & - & - & 21.00 \\
\hline $\mathrm{BG}$ & 20.00 & - & - & - & - & - & - & - & - & 20.00 \\
\hline $\mathrm{CZ}$ & 19.00 & - & - & 1.00 & - & - & 1.00 & - & - & 21.00 \\
\hline $\mathrm{DE}$ & 19.00 & - & - & - & - & - & - & - & - & 19.00 \\
\hline DK & 25.00 & - & - & - & - & - & - & - & - & 25.00 \\
\hline $\mathrm{EE}$ & 18.00 & - & - & 2.00 & - & - & - & - & - & 20.00 \\
\hline ES & 16.00 & - & - & 2.00 & - & 3.00 & - & - & - & 21.00 \\
\hline FI & 22.00 & - & - & 1.00 & - & - & 1.00 & - & - & 24.00 \\
\hline FR & 19.60 & - & - & - & - & - & - & 0.40 & - & 20.00 \\
\hline GB & 17.50 & - & -2.50 & 2.50 & 2.50 & - & - & - & - & 20.00 \\
\hline HR & 22.00 & - & - & 1.00 & - & 2.00 & - & - & - & 25.00 \\
\hline $\mathrm{HU}$ & 20.00 & - & - & 5.00 & - & 2.00 & - & - & - & 27.00 \\
\hline $\mathrm{IE}$ & 21.00 & - & 0.50 & -0.50 & - & 2.00 & - & - & - & 23.00 \\
\hline IT & 20.00 & - & - & - & 1.00 & - & - & 1.00 & - & 22.00 \\
\hline LU & 15.00 & - & - & - & - & - & - & - & 2.00 & 17.00 \\
\hline LV & 18.00 & - & 3.00 & - & 1.00 & -1.00 & - & - & - & 21.00 \\
\hline NL & 19.00 & - & - & - & - & 2.00 & - & - & - & 21.00 \\
\hline $\mathrm{NO}$ & 25.00 & - & - & - & - & - & - & - & - & 25.00 \\
\hline PL & 22.00 & - & - & - & 1.00 & - & - & - & - & 23.00 \\
\hline PT & 21.00 & - & -1.00 & 1.00 & 2.00 & - & - & - & - & 23.00 \\
\hline RO & 19.00 & - & - & 5.00 & - & - & - & - & - & 24.00 \\
\hline $\mathrm{SE}$ & 25.00 & - & - & - & - & - & - & - & - & 25.00 \\
\hline SI & 20.00 & - & - & - & - & - & 2.00 & - & - & 22.00 \\
\hline SK & 19.00 & - & - & - & 1.00 & - & - & - & - & 20.00 \\
\hline$\varnothing$ & 20.13 & - & 0 & 2.00 & 1.42 & 1.67 & 1.33 & 0.70 & 2.00 & 22.04 \\
\hline
\end{tabular}


Panel B: CIT Rates and Changes for Sample Countries

\begin{tabular}{|c|c|c|c|c|c|c|c|c|c|c|}
\hline & 2007 & $\Delta 2008$ & $\Delta 2009$ & $\Delta 2010$ & $\Delta 2011$ & $\Delta 2012$ & $\Delta 2013$ & $\Delta 2014$ & $\Delta 2015$ & 2015 \\
\hline $\mathrm{BE}$ & 33.99 & - & - & - & - & - & - & - & - & 33.99 \\
\hline $\mathrm{BG}$ & 10.00 & - & - & - & - & - & - & - & - & 10.00 \\
\hline $\mathrm{CZ}$ & 24.00 & -3.00 & -1.00 & -1.00 & - & - & - & - & - & 19.00 \\
\hline $\mathrm{DE}$ & 39.35 & -8.40 & - & - & - & - & - & - & - & 30.95 \\
\hline DK & 25.00 & - & - & - & - & - & - & -0.50 & -2.50 & 22.00 \\
\hline $\mathrm{EE}$ & 22.00 & -1.00 & - & - & - & - & - & - & -1.00 & 20.00 \\
\hline ES & 38.01 & -2.27 & - & - & -0.49 & - & - & - & -1.85 & 33.40 \\
\hline FI & 26.00 & - & - & - & - & -1.50 & - & -4.50 & - & 20.00 \\
\hline FR & 34.43 & - & - & 0.99 & - & 1.64 & - & 1.87 & - & 38.93 \\
\hline GB & 30.00 & -2.00 & - & - & -2.00 & -2.00 & -1.00 & -2.00 & -1.00 & 20.00 \\
\hline HR & 20.00 & - & - & - & - & - & - & - & - & 20.00 \\
\hline $\mathrm{HU}$ & 20.00 & - & - & - & - & - & - & - & - & 20.00 \\
\hline $\mathrm{IE}$ & 12.50 & - & - & - & - & - & - & - & - & 12.50 \\
\hline IT & 37.25 & -5.95 & - & - & - & - & - & - & - & 31.30 \\
\hline LU & 29.63 & - & -1.04 & - & 0.21 & - & 0.42 & - & - & 29.00 \\
\hline LV & 15.00 & - & - & - & - & - & - & - & - & 15.00 \\
\hline $\mathrm{NL}$ & 25.50 & - & - & - & -0.50 & - & - & - & - & 25.00 \\
\hline $\mathrm{NO}$ & 28.00 & - & - & - & - & - & - & -1.00 & - & 27.00 \\
\hline PL & 19.00 & - & - & - & - & - & - & - & - & 19.00 \\
\hline $\mathrm{PT}$ & 26.50 & - & - & 2.50 & - & 2.50 & - & - & -2.00 & 29.50 \\
\hline RO & 16.00 & - & - & - & - & - & - & - & - & 16.00 \\
\hline $\mathrm{SE}$ & 28.00 & - & -2.00 & - & - & - & -4.00 & - & - & 22.00 \\
\hline SI & 23.00 & -1.00 & -1.00 & -1.00 & - & -2.00 & -1.00 & - & - & 17.00 \\
\hline SK & 19.00 & - & - & - & - & - & 4.00 & -1.00 & - & 22.00 \\
\hline$\varnothing$ & 25.09 & -3.37 & -1.26 & 0.37 & -0.70 & -0.27 & -0.32 & -1.19 & -1.67 & 23.07 \\
\hline
\end{tabular}

This table maps VAT and CIT rate changes in Panel A and B, respectively, of the countries in our sample for the period 2007-2015. The rate changes are presented in percentage points. 
Table 14: Total Sales in the Information and Communications Services Sector (NACE 58-63)

\begin{tabular}{lcccc}
\hline \multicolumn{1}{c}{ Total sales in: } & 2012 & 2013 & 2014 & 2015 \\
\hline Eurostat & $134,290.6$ & $128,450.9$ & $133,787.2$ & $137,372.1$ \\
Dataset & $170,000.0$ & $175,000.0$ & $178,000.0$ & $171,000.0$ \\
$\Delta \%$ & $+27 \%$ & $+36 \%$ & $+33 \%$ & $+24 \%$ \\
\hline
\end{tabular}

This table compares the coverage of total sales of affiliates in the information and communication services sector in the regression sample (Dataset) with the consolidated statistics of sales in this sector provided by the statistical office of the European Union (Eurostat (online). 
Figure 4: Value-added Taxation of Digital Services in Europe

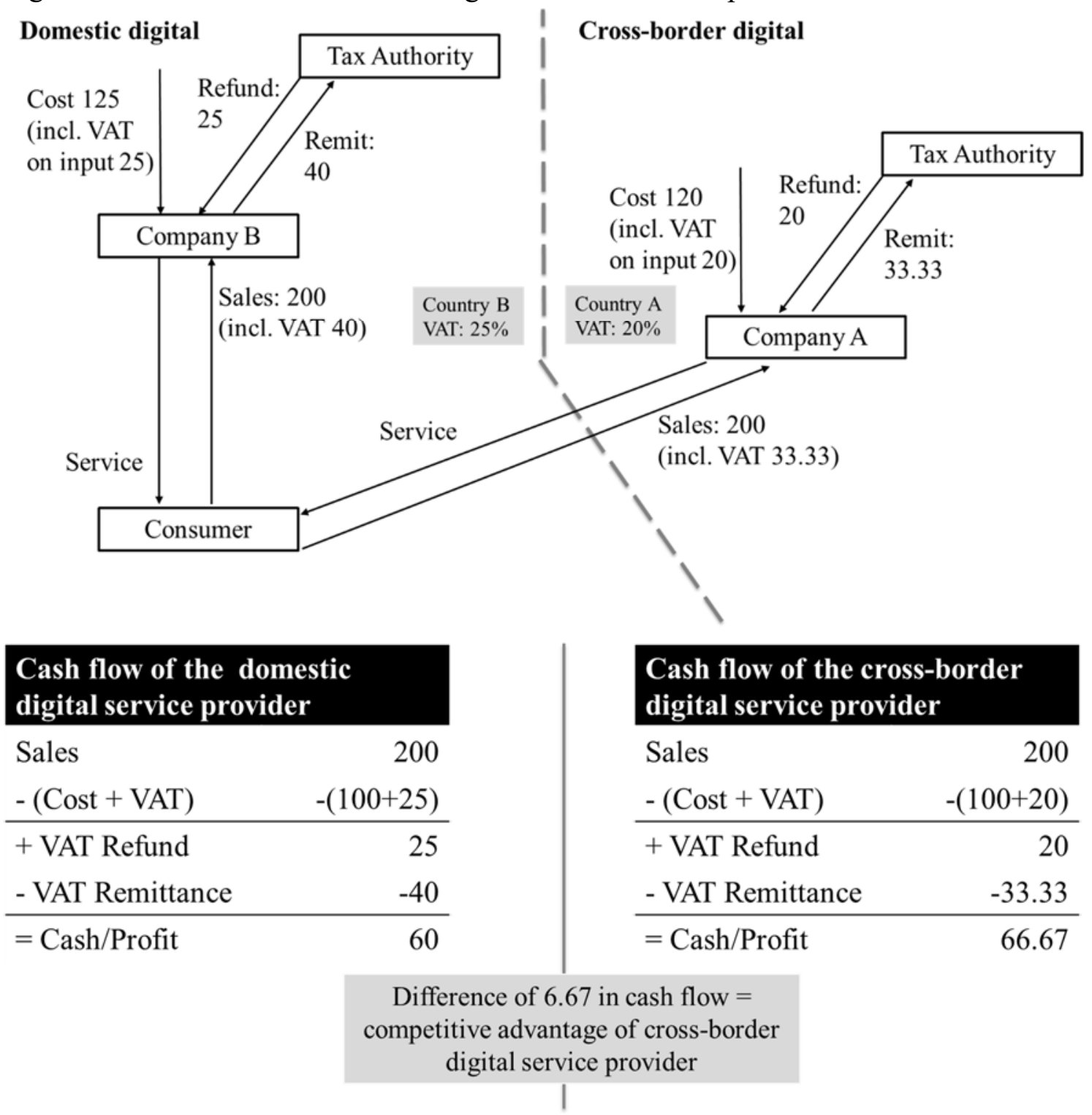

\begin{abstract}
This figure illustrates the value-added taxation of digital service providers delivering to a final customer in Europe. The cross-border digital service provider is established in country A, which charges VAT at a rate of $20 \%$. The domestic digital service provider and the final consumer (non-taxable person for VAT purposes) are established in country B, which charges VAT at a rate of $25 \%$. Both companies incur input costs of 100 (net, plus VAT). The domestic digital service provider, company B, is liable to input VAT of $25(100 * 25 \%)$ and is later granted an input VAT refund of 25 . The digital service is sold to the consumer at a price of 200 (gross). The delivery of this service is taxable at the domestic rate of $25 \%$. The gross price of 200 thus includes VAT of 40 (25\% on a net price of 160$)$, which the company remits (on behalf of the final consumer) to the tax authority of country B. The service provider realizes a net profit of 60 (net sales price of 160 less input cost of 100). The delivery of cross-border digital services by company A to the final consumer is taxable in the country of the service provider (origin principle; applicable until 2014) at a rate of $20 \%$. The gross price of 200 includes VAT of $33.33(20 \%$ on a net price of 166.67), which the company remits (on behalf of the final consumer) to the tax authority of country A. The service provider realizes a net profit of 66.67 (net sales price of 166.67 less input cost of 100). Hence, the cross-border digital service provider's profit is 6.67 higher than the domestic service provider's profit.
\end{abstract}


Table 15: Classification of Digital Services (NACE Rev. 2 Codes)

NACE Rev. 2 Code Description

\begin{tabular}{l|l}
\hline 5821 & Publishing of computer games \\
5829 & Other software publishing \\
5913 & Motion picture, video and television programme distribution activities \\
5920 & Sound recording and music publishing activities \\
6209 & Other information technology and computer service activities \\
6311 & Data processing, hosting and related activities \\
6312 & Web portals \\
6391 & News agency activities \\
6399 & Other information service activities n.e.c. \\
7722 & Renting of video tapes and disks \\
8559 & Other education n.e.c. \\
9200 & Gambling and betting activities \\
\hline
\end{tabular}

The NACE Rev. 2 Codes and descriptions are based on the industry classification published by Eurostat, the Statistical Office of the European Communities. The selection of NACE Rev. 2 Codes covers potential digital services. The complete segmentation of economic activities is available at http://ec.europa.eu/eurostat/documents/3859598/5902521/KS-RA-07-015-EN.PDF. N.e.c. is short for not elsewhere classified. 
Figure 5: Distribution of Country-Year Tax Rate Distances to Mean

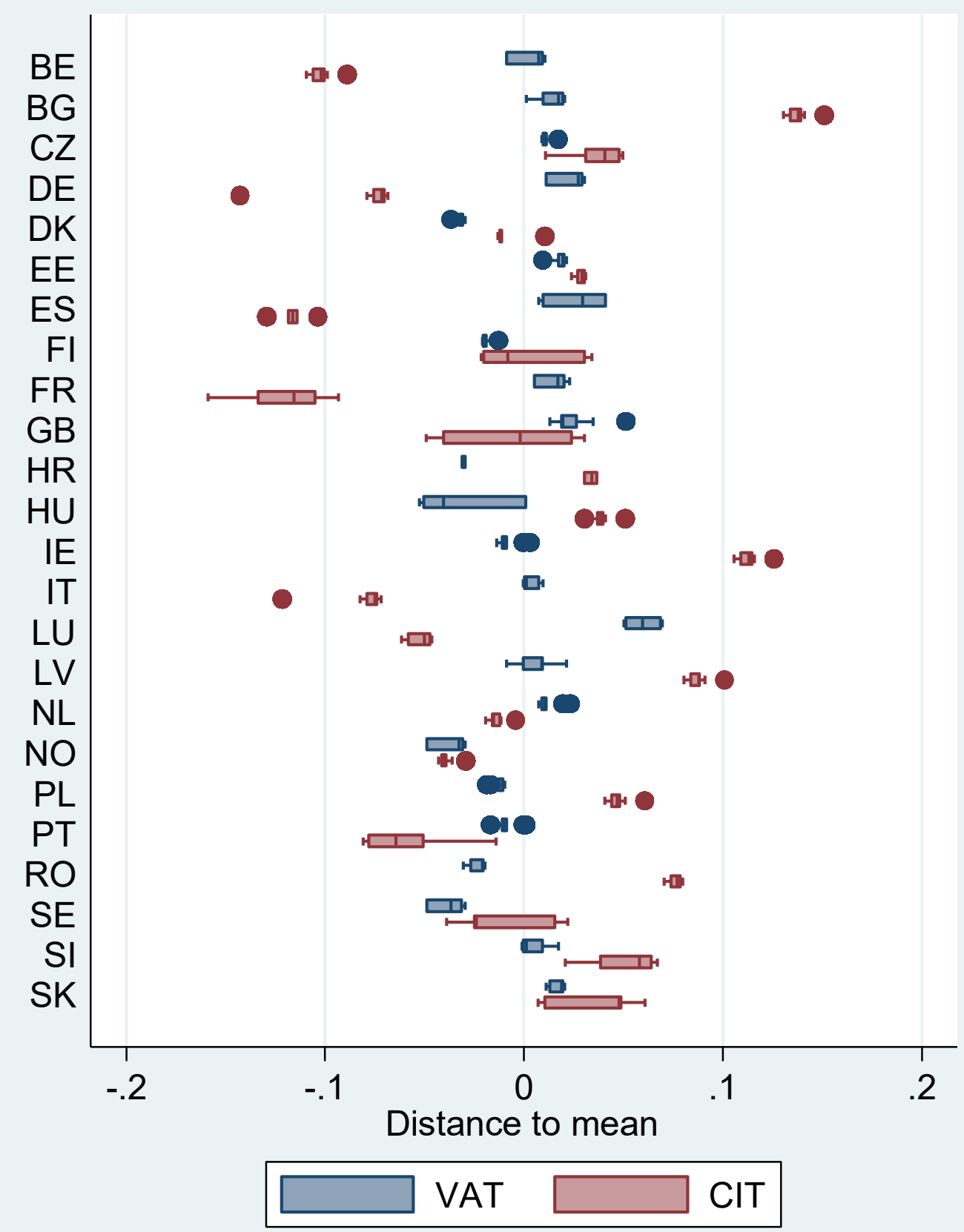

The red and blue boxes in this figure indicate the distribution of affiliate-year observations within the $25^{\text {th }}$ and $75^{\text {th }}$ percentile of the difference between the country's tax rate and the average tax rate across countries in the EU in the period 2007-2015. The median is marked with a vertical line in the box. Values outside the $25^{\text {th }}$ and $75^{\text {th }}$ percentile are indicated as dots. The country's difference to means are calculated as follows. E.g. the VAT distance to mean of Italy in $2010=$ mean(VAT 2010)-VAT(Italy in 2010); i.e. positive values suggest more attractive than average tax rate (country's tax rate is lower than the mean). 
Figure 6: Consumption and Corporate Income Tax Rate Policies 2015

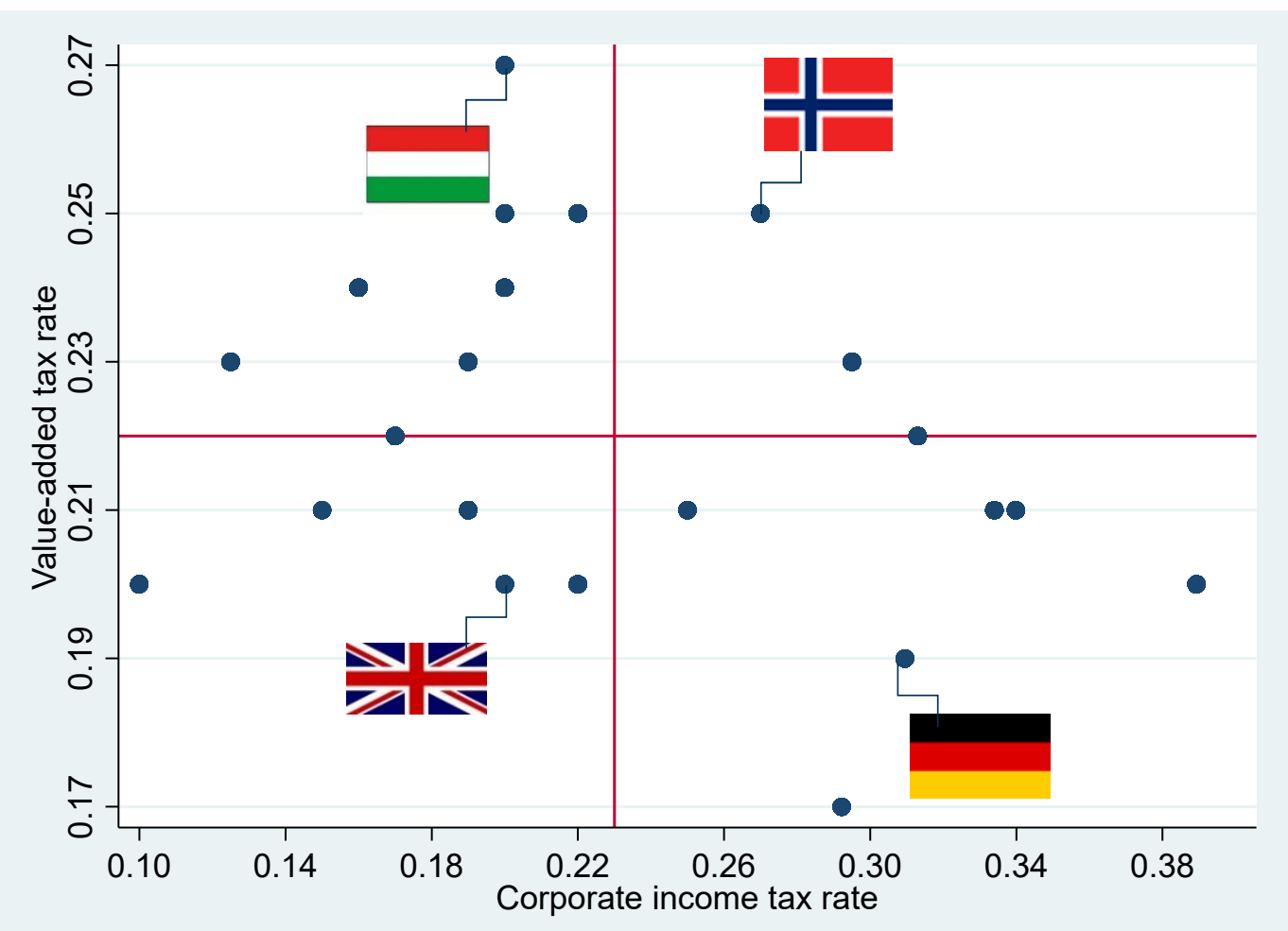

The blue points in this figure indicate the VAT respectively CIT rate applicable in the 24 countries included in our sample for the year 2015. The red lines indicate the mean VAT respectively CIT rate in 2015 across the 24 countries included in our regression analysis. 
Table 16: Robustness Tests: REGHDFE-Regression to Calculate $\triangle V A T$

\begin{tabular}{lcc}
\hline Dep. Var.: & $(1)$ & $(2)$ \\
LogSales & Reg. HDFE & VAT*Firm FE \\
\hline VAT & $-0.5201^{* * *}$ & \\
& $(0.0694)$ & \\
CIT & $-0.1451^{* * *}$ & $0.1478^{* * *}$ \\
& $(0.0334)$ & $(0.0433)$ \\
Ttc_c & $0.0002^{* * *}$ & $0.0003^{* * *}$ \\
& $(0.0000)$ & $(0.0000)$ \\
LogPexp & $0.3487^{* * *}$ & $0.3344^{* * *}$ \\
& $(0.0041)$ & $(0.0055)$ \\
LogAssets & $0.4183^{* * *}$ & $0.3835^{* * *}$ \\
& $(0.0033)$ & $(0.0042)$ \\
LogGDP & $0.4420^{* * *}$ & $0.1822^{* * *}$ \\
& $(0.0186)$ & $(0.0240)$ \\
LogConsPrice & $-0.1694^{* * *}$ & $0.0652^{* * *}$ \\
& $(0.0188)$ & $(0.0229)$ \\
Inflation & $1.1208^{* * *}$ & $0.9381 * * *$ \\
& $(0.0736)$ & $(0.0778)$ \\
\hline Observations & 299,901 & 299,901 \\
R-squared (within) & & 0.491 \\
Firm FE & YES & YES \\
Year FE & YES & YES \\
\hline
\end{tabular}

This table reports the regression results when running the regression of reported sales on the explanatory variables as in Column (3) of Table 5 using the high dimensional fixed effects estimator by Correia (2016) (reghdfe command in STATA). Column (1) reports results replicating Column (3) of Table 5 with affiliate fixed effects. Column (2) reports results when the VAT rate is interacted with the affiliate fixed effects. The results of this regression, i.e. the point estimates on the interaction term, are used to construct the variable $\triangle V A T$. 